\title{
A 15-year record (2001-2015) of the ratio of nitrate to non-sea-salt sulfate in precipitation over East Asia
}

\author{
Syuichi Itahashi ${ }^{1, a}$, Keiya Yumimoto ${ }^{2}$, Itsushi Uno ${ }^{2}$, Hiroshi Hayami ${ }^{1}$, Shin-ichi Fujita ${ }^{1}$, Yuepeng Pan $^{3}$, and \\ Yuesi Wang ${ }^{3}$ \\ ${ }^{1}$ Environmental Science Research Laboratory, Central Research Institute of Electric Power Industry (CRIEPI), \\ 1646 Abiko, Abiko, Chiba 270-1194, Japan \\ ${ }^{2}$ Research Institute for Applied Mechanics (RIAM), Kyushu University, 6-1 Kasuga Park, Kasuga, Fukuoka 816-8580, Japan \\ ${ }^{3}$ State Key Laboratory of Atmospheric Boundary Layer Physics and Atmospheric Chemistry (LAPC), \\ Institute of Atmospheric Physics (IAP), Chinese Academy of Sciences (CAS), Beijing 100029, China \\ a now at: Department of Marine, Earth, and Atmospheric Sciences (MEAS), North Carolina State University (NCSU), \\ 2800 Faucette Dr., Raleigh, North Carolina 27695, USA
}

Correspondence: Syuichi Itahashi (isyuichi@criepi.denken.or.jp)

Received: 11 September 2017 - Discussion started: 16 October 2017

Revised: 5 January 2018 - Accepted: 22 January 2018 - Published: 28 February 2018

\begin{abstract}
Acidifying species in precipitation can have severe impacts on ecosystems. The chemical composition of precipitation is directly related to the amount of precipitation; accordingly, it is difficult to identify long-term variation in chemical concentrations. The ratio of the nitrate $\left(\mathrm{NO}_{3}^{-}\right)$ to non-sea-salt sulfate (nss- $\mathrm{SO}_{4}^{2-}$ ) concentration in precipitation on an equivalent basis (hereinafter, Ratio) is a useful index to investigate the relative contributions of these acidifying species. To identify the long-term record of acidifying species in precipitation over East Asia, the region with the highest emissions worldwide, we compiled groundbased observations of the chemical composition of precipitation over China, Korea, and Japan from 2001 to 2015 based on the Acid Deposition Monitoring Network in East Asia (EANET). The spatial coverage was limited, but additional monitoring data for Japan, southern China, and northern China around Beijing were utilized. The period of analysis was divided into three phases: Phase I (2001-2005), Phase II (2006-2010), and Phase III (2011-2015). The behaviors of $\mathrm{NO}_{3}^{-}$and nss- $\mathrm{SO}_{4}^{2-}$ concentrations and hence the Ratio in precipitation were related to these precursors. The anthropogenic $\mathrm{NO}_{x}$ and $\mathrm{SO}_{2}$ emissions and the $\mathrm{NO}_{x} / \mathrm{SO}_{2}$ emission ratio were analyzed. Further, satellite observations of the $\mathrm{NO}_{2}$ and $\mathrm{SO}_{2}$ column density to capture the variation in emissions were applied. We found that the longterm trend in the $\mathrm{NO}_{3}^{-}$concentration in precipitation was
\end{abstract}

not related to the variation in $\mathrm{NO}_{x}$ emission and the $\mathrm{NO}_{2}$ column. In comparison, the nss- $\mathrm{SO}_{4}^{2-}$ concentration in precipitation over China, Korea, and Japan was partially connected to the changes in $\mathrm{SO}_{2}$ emissions from China, but the trends were not significant. The long-term trends of Ratio over China, Korea, and Japan were nearly flat during Phase I, increased significantly during Phase II, and were essentially flat again during Phase III. This variation in Ratio in East Asia clearly corresponded to the $\mathrm{NO}_{x} / \mathrm{SO}_{2}$ emission ratio and the $\mathrm{NO}_{2} / \mathrm{SO}_{2}$ column ratio in China. The initial flat trend during Phase I was due to increases in both $\mathrm{NO}_{x}$ and $\mathrm{SO}_{2}$ emissions in China, the significantly increasing trend during Phase II was triggered by the increase in $\mathrm{NO}_{x}$ emissions and decrease in $\mathrm{SO}_{2}$ emissions in China, and the return to a flat trend during Phase III was caused by declines in both $\mathrm{NO}_{x}$ and $\mathrm{SO}_{2}$ emissions in China. These results suggest that emissions in China had a significant impact not only on China but also on downwind precipitation chemistry during the 15-year period of 2001-2015. In terms of wet deposition, the $\mathrm{NO}_{3}^{-}$wet deposition over China, Korea, and Japan did not change dramatically, but the nss- $\mathrm{SO}_{4}^{2-}$ wet deposition declined over China, Korea, and Japan from Phase II to III. These declines were caused by a strong decrease in the nss- $\mathrm{SO}_{4}^{2-}$ concentration in precipitation accompanied by a reduction in $\mathrm{SO}_{2}$ emission from China, which counteracted 
the increase in precipitation. These findings indicated that the acidity of precipitation shifted from sulfur to nitrogen.

\section{Introduction}

Accompanying the recent acceleration of anthropogenic emissions in Asia, atmospheric deposition in Asia has been a major focus worldwide (Vet et al., 2014). According to the Clean Air Status and Trends Networks (CASTNET) in the US (Sickles II and Shadwick, 2015) and the European Monitoring and Evaluation Programme (EMEP) in Europe (Tørseth et al., 2012), in Japan, which is located in the downwind region of the Asian continent, the total wet and dry deposition have surpassed those of both the US and Europe (Endo et al., 2011; Ban et al., 2016). In terms of the wet deposition of nitrogen and sulfur compounds over Japan, the influence of anthropogenic emissions from China has been determined via chemical transport model simulations (Kuribayashi et al., 2012; Kajino et al., 2011, 2013; Morino et al., 2011).

The amount of wet deposition is affected by the amount of precipitation. For this reason, the ratio of the nitrate $\left(\mathrm{NO}_{3}^{-}\right)$ concentration to non-sea-salt sulfate (nss- $\mathrm{SO}_{4}^{2-}$ ) concentration in precipitation on an equivalence basis, hereafter referred to as Ratio, is useful for evaluating the relative contributions of nitrogen and sulfur to the acidity of precipitation. Ratio in Japan was about 0.41 between 1987 and 1990 (Fujita et al., 2003). Over western Japan, Ratio increased substantially by $0.09-0.17$ between 1987 and 1996, reaching about 0.5 in the late 1990s. This corresponded to a large increase in $\mathrm{NO}_{x}$ emissions compared with $\mathrm{SO}_{2}$ emissions across East Asia (Takahashi and Fujita, 2000). In our previous studies (Itahashi et al., 2014a, 2015), we showed that the Ratio trend in precipitation over Japan remained flat at around $0.5-0.6$ between 2000 and 2005, with a subsequent increase to $0.6-0.7$ between 2006 and 2011. During this period, the $\mathrm{NO}_{x} / \mathrm{SO}_{2}$ emission ratio in Japan constantly decreased, and changes in Ratio closely followed the changes in the $\mathrm{NO}_{x} / \mathrm{SO}_{2}$ emission ratio in China. A significant increase in Ratio between 2006 and 2011 was also found over both China and Korea. A correlation between Ratio in China, Korea, and Japan and the $\mathrm{NO}_{x} / \mathrm{SO}_{2}$ emission ratio in China was detected. A sensitivity simulation via a regional chemical transport model of Chinese anthropogenic emissions indicated the important contribution of $\mathrm{NO}_{x}$ emissions near the source region and the high impact of $\mathrm{SO}_{2}$ emissions over downwind regions. Identifying the importance of acidity via nitrogen and sulfur is critical to mitigate ecosystem effects, such as soil acidification (Zhao et al., 2009) and surface water acidification (Yamashita et al., 2016). Similar studies of Ratio (or the inverse of Ratio, defined as the ratio of the nss$\mathrm{SO}_{4}^{2-}$ to $\mathrm{NO}_{3}^{-}$concentration in precipitation) have been conducted in northern China (Wang et al., 2012), Nanjing (Tu et al., 2005), southeastern China (Cui et al., 2014), and the Pearl River Delta region (Lu et al., 2015).

We next consider recent changes in Ratio in East Asia according to recent changes in anthropogenic emissions. In our previous studies (Itahashi et al., 2014a, 2015), which considered data obtained in 2000-2011, emissions from China exhibited a transition from a continuously increasing trend. $\mathrm{NO}_{x}$ emissions in China have been rising steadily (Kurokawa et al., 2013; Itahashi et al., 2014b), whereas $\mathrm{SO}_{2}$ emissions in China peaked in 2005-2006 and subsequently declined due to the introduction of flue-gas desulfurization systems in China's 11th Five-Year Plan (2006-2010) (Kurokawa et al., 2013; Itahashi et al., 2012). Recently, it has been reported that $\mathrm{NO}_{x}$ emissions in China declined after 2011-2012 (Irie et al., 2016; Xia et al., 2016; Krotkov et al., 2016; van der A et al., 2017). To determine the result of this change, we revisited and updated an analysis of precipitation data in relation to emission variation over East Asia. We compiled precipitation observations over the 15 -year period between 2001 and 2015. Considering the drastic change in emissions from China, the analysis period was divided into three parts: Phase I (2001-2005), Phase II (2006-2010), and Phase III (2011-2015). This study extends our previous studies (Itahashi et al., 2014a, 2015) in the following respects. First, this study incorporates additional data obtained over southern China and northern China around Beijing. The groundbased observation network in East Asia does not cover northern China, which is characterized by a large urban population and therefore contributes substantial anthropogenic emissions (e.g., Pan et al., 2012, 2013). Although these additional data over southern and northern China are limited to 1 year or a few years, this approach of combining and comparing datasets will further improve our understanding of precipitation chemistry over all of China. Additionally, this study uses satellite observations of $\mathrm{NO}_{2}$ and $\mathrm{SO}_{2}$ column density as a proxy to estimate recent emission changes. This can further enhance our knowledge of the current emission status. Analyses of long-term precipitation chemistry are still limited. For example, precipitation chemistry over periods of longer than 10 years has been evaluated for Guangzhou in 1983-2010 (Fang et al., 2013), Shenzhen in 1986-2006 (Huang et al., 2008), Lijiang in 1989-2006 (Zhang et al., 2012), Nanjing in 1992-2003 (Tu et al., 2005) and Tieshanping in 2001-2013 (Yu et al., 2017). This long-term, 15-year analysis provides a comprehensive overview of the precipitation chemistry over East Asia.

This paper is structured as follows. Section 2 introduces the dataset used in this study, which includes ground-based observations, emission inventories, and satellite observations that were applied as a proxy for emission levels. Section 3 is dedicated to the results and discussion. First, Sect. 3.1 presents the long-term trends for $\mathrm{NO}_{3}^{-}$and nss- $\mathrm{SO}_{4}^{2-}$ in China, Korea, and Japan. Section 3.2 describes the intensive analysis of Ratio and its relation to emissions. Section 3.3 

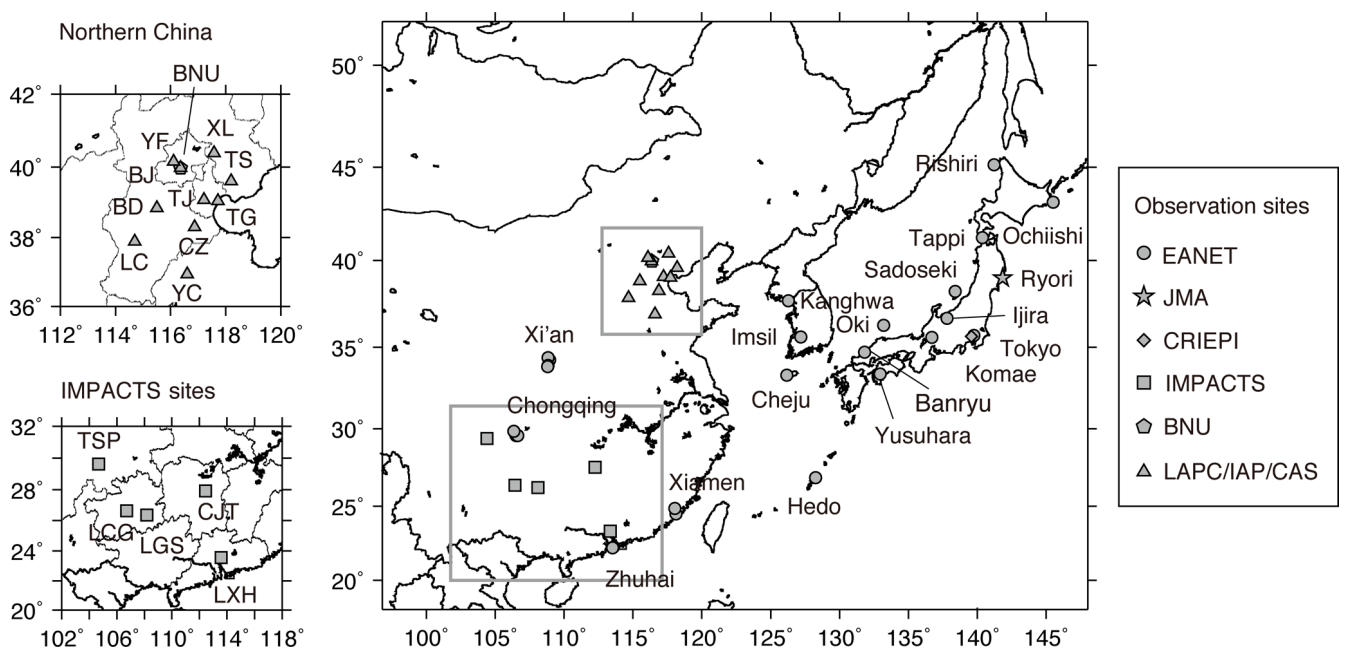

Figure 1. Geographical mapping of observation sites included in this study. Detailed information about each observation site is provided in Table 1.

explores the analysis of wet deposition. Finally, Sect. 4 summarizes this research and outlines future perspectives.

\section{Dataset}

\subsection{Ground-based observations}

The ground-based observations used in this study are spatially mapped in Fig. 1. Detailed information for the observation period, including latitude $\left({ }^{\circ} \mathrm{N}\right)$, longitude $\left({ }^{\circ} \mathrm{E}\right)$, elevation (meters above sea level, a.s.1.), and the classification of each site, is listed in Table 1. The observation dataset for the chemical composition of precipitation, which was compiled by the Acid Deposition Monitoring Network in East Asia (EANET) program (EANET, 2017), was mainly used in this study. In China, EANET observations were obtained over three areas in southern China (Zhuhai, Xiamen, and Chongqing) and one area in central China (Xi'an), for a total of 10 sites. In Korea, EANET observations from three sites (Cheju, Imsil, and Kanghwa) were available. In Japan, data for a total of 11 sites were available on EANET. Among these 11 sites, the data obtained at Ogasawara, which is located in the northwest Pacific Ocean $\left(27.09^{\circ} \mathrm{N}, 142.22^{\circ} \mathrm{E}\right.$, $230 \mathrm{~m}$ a.s.l.), includes estimates of the chemical composition of precipitation that are below the detection limit, that is, $11.8 \%$ for $\mathrm{NO}_{3}^{-}$and $7.7 \%$ for nss- $\mathrm{SO}_{4}^{2-}$. Therefore, the data from Ogasawara were excluded. Samples were collected using a wet-only sampler at a daily interval, except for Banryu (sampled weekly during 2001-2015) and Ijira (sampled weekly in 2001). Concentrations of $\mathrm{NO}_{3}^{-}$and $\mathrm{SO}_{4}^{2-}$ in precipitation were determined by ion chromatography and qualified via ion balance and conductivity agreement. The completeness of the data was determined from the precipitation coverage duration and total precipitation amount
(EANET, 2000, 2010). In Japan, two sites (Ryori and Komae) were included in the study. Under the Global Atmosphere Watch (GAW) program of the World Meteorological Organization (WMO GAW, 2004), the Japan Meteorological Agency (JMA) has been conducting observations of the atmospheric concentration and deposition at the northern, remote Ryori site since 1976; observations of deposition at Ryori ended in 2011. Samples were collected using a wet-only sampler at a daily interval at Ryori. The Central Research Institute of Electric Power Industry (CRIEPI) conducted continuous monitoring of precipitation chemistry. The CRIEPI data obtained at Komae, which is located near Tokyo, span 1987 to the present (Fujita et al., 2000). As we have more fully described in our previous studies (Itahashi et al., 2014a, 2015), CRIEPI monitoring was also conducted at Goto Island, which is located at the western edge of Japan. However, the period of coverage was limited to February 2000 to April 2003, so we excluded the Goto data from this study. Samples were collected using a wet-only sampler at 10-day intervals in Komae. For the EANET, JMA, and CRIEPI monthly mean datasets, the nss- $\mathrm{SO}_{4}^{2-}$ concentration (in $\mathrm{mol} \mathrm{L}^{-1}$ ) was calculated from the conservative assumption that sodium $\left(\mathrm{Na}^{+}\right)$is a sea salt tracer, using the following equation:

nss- $\mathrm{SO}_{4}^{2-}=\mathrm{SO}_{4}^{2-}-0.06028 \times \mathrm{Na}^{+}$

To analyze the long-term behavior of the dataset over the 15-year period of 2001-2015, outliers in the observation of EANET, JMA, and CRIEPI were carefully examined according to method used in Itahashi et al. (2015). The volumeweighted monthly mean concentrations of $\mathrm{NO}_{3}^{-}$, nss- $\mathrm{SO}_{4}^{2-}$, and Ratio in precipitation were analyzed using the SmirnovGrubbs outlier test at each site. In this study, the outliers for Ratio were directly checked. In this method, outliers were detected one at a time, assuming that the data likely followed 
Table 1. Locations of observation sites included in this study.

\begin{tabular}{|c|c|c|c|c|c|c|c|}
\hline & Country & Site & Period & Latitude $\left({ }^{\circ} \mathrm{N}\right)$ & Longitude $\left({ }^{\circ} \mathrm{E}\right)$ & Elevation (m a.s.l.) & Classification \\
\hline \multirow[t]{27}{*}{ EANET } & China & Zhuhai & & & & & \\
\hline & & Xiangzhou & $2001-2015$ & 22.27 & 113.57 & 40 & urban \\
\hline & & Zhuxiandong & 2001-2015 & 22.20 & 113.52 & 45 & urban \\
\hline & & Xiamen & & & & & \\
\hline & & Hongwen & $2001-2015$ & 24.47 & 118.13 & 50 & urban \\
\hline & & Xiaoping & $2001-2015$ & 24.85 & 118.03 & 686 & remote \\
\hline & & Chongqing & & & & & \\
\hline & & Guanyinqiao & 2001-2007 & 29.57 & 106.52 & 262 & urban \\
\hline & & Haifu & $2008-2015$ & 29.62 & 106.50 & 317 & urban \\
\hline & & Jinyunshan & $2001-2015$ & 29.82 & 106.37 & 800 & rural \\
\hline & & Xi'an & & & & & \\
\hline & & Shizhan & 2001-2015 & 34.23 & 108.95 & 400 & urban \\
\hline & & Weishuiyuan & 2001-2006 & 34.37 & 108.85 & 366 & rural \\
\hline & & Jiwozi & $2001-2015$ & 33.83 & 108.80 & 1800 & remote \\
\hline & Korea & Cheju & 2001-2015 & 33.30 & 126.17 & 72 & remote \\
\hline & & Imsil & $2001-2015$ & 35.60 & 127.18 & - & rural \\
\hline & & Kanghwa & 2001-2015 & 37.70 & 126.28 & 150 & urban \\
\hline & Japan & Hedo & 2001-2015 & 26.87 & 128.25 & 60 & remote \\
\hline & & Yusuhara & $2001-2015$ & 33.38 & 132.94 & 790 & remote \\
\hline & & Banryu & $2001-2015$ & 34.68 & 131.80 & 53 & urban \\
\hline & & Ijira & 2001-2015 & 35.57 & 136.69 & 140 & rural \\
\hline & & Tokyo & $2007-2015$ & 35.69 & 139.76 & 26 & urban \\
\hline & & Oki & $2001-2015$ & 36.29 & 133.19 & 90 & remote \\
\hline & & Sadoseki & $2001-2015$ & 38.25 & 138.40 & 136 & remote \\
\hline & & Tappi & $2001-2015$ & 41.25 & 140.35 & 106 & remote \\
\hline & & Ochiishi & 2003-2015 & 43.16 & 145.50 & 49 & remote \\
\hline & & Rishiri & $2001-2015$ & 45.12 & 141.21 & 40 & remote \\
\hline JMA & Japan & Ryori & 2001-2011 & 39.03 & 141.82 & 260 & \\
\hline CRIEPI & Japan & Komae & $2001-2015$ & 35.64 & 139.58 & 27 & \\
\hline \multirow[t]{9}{*}{ IMPACTS } & China & Guangdong & & & & & \\
\hline & & Liuxihe (LXH) & $2002-2003$ & 23.55 & 113.58 & 500 & \\
\hline & & Guizhou & & & & & \\
\hline & & Leigongshan (LGS) & $2002-2003$ & 26.37 & 108.18 & $1630-1735$ & \\
\hline & & Liuchongguan (LCG) & 2001-2003 & 26.63 & 106.72 & $1320-1400$ & \\
\hline & & Hunan & & & & & \\
\hline & & Caijiatang (CJT) & $2001-2003$ & 27.92 & 112.43 & $450-500$ & \\
\hline & & Chongqing & & & & & \\
\hline & & Tieshanping (TSP) & 2001-2003 & 29.63 & 104.68 & $450-500$ & \\
\hline \multirow[t]{2}{*}{ BNU } & China & Beijing & & & & & \\
\hline & & Beijing Normal University & 2005 & 39.96 & 116.37 & 40 & \\
\hline \multirow[t]{14}{*}{ LAPC/IAP/CAS } & China & Shandong & & & & & \\
\hline & & Yucheng (YC) & $2008-2010$ & 36.85 & 116.55 & 23 & \\
\hline & & Hebei & & & & & \\
\hline & & Luancheng (LC) & 2008-2010 & 37.89 & 114.69 & 57 & \\
\hline & & Cangzhou (CZ) & $2008-2010$ & 38.30 & 116.87 & 10 & \\
\hline & & Baoding (BD) & 2008-2010 & 38.85 & 115.50 & 21 & \\
\hline & & Tangshan (TS) & $2008-2010$ & 39.60 & 118.20 & 24 & \\
\hline & & Xinglong (XL) & 2008-2010 & 40.38 & 117.57 & 872 & \\
\hline & & Tianjin & & & & & \\
\hline & & Tanggu (TG) & 2008-2010 & 39.04 & 117.72 & 0 & \\
\hline & & Tianjin (TJ) & $2008-2010$ & 39.08 & 117.21 & 6 & \\
\hline & & Beijing & & & & & \\
\hline & & Beijing (BJ) & $2008-2010$ & 39.96 & 116.36 & 57 & \\
\hline & & Yangfang (YF) & $2008-2010$ & 40.15 & 116.10 & 73 & \\
\hline
\end{tabular}


an approximately normal distribution. The hypothesis of no outliers is rejected when

$$
G=\max _{i=1, \ldots, N} \frac{\left|C_{i}-\bar{C}\right|}{s}>\frac{N-1}{\sqrt{N}} \sqrt{\frac{t_{(\alpha / 2 N, N-2)}^{2}}{N-2+t_{(\alpha / 2 N, N-2)}^{2}}}
$$

where $N, \bar{C}$, and $s$ are the number, mean, and standard deviation, respectively, of $\mathrm{NO}_{3}^{-}$or nss- $\mathrm{SO}_{4}^{2-}$ concentrations in precipitation or Ratio in precipitation $\left(C_{i}\right) . t_{(\alpha / 2 N, N-2)}^{2}$ denotes the critical value of the $t$ distribution with $(N-2)$ degrees of freedom and a significance level of $(\alpha / 2 N)$. Outlier detection and removal were iterated until the dataset satisfied the specified significance level of 0.05 . Following the above criteria, 4.7, 3.8, and $4.4 \%$ of data points for $\mathrm{NO}_{3}^{-}$, nss- $\mathrm{SO}_{4}^{2-}$, and Ratio in precipitation, respectively, were discarded from the China dataset; 5.0, 3.0, and 3.0\% of these were discarded from the Korea dataset; and 2.4, 1.5, and $1.6 \%$ of these were discarded from the Japan dataset. Finally, the annual mean concentrations of $\mathrm{NO}_{3}^{-}$, nss-SO ${ }_{4}^{2}$, and the annual mean Ratio in precipitation were calculated from the monthly mean data when at least 9 months of data were available for a given year at the site. For the treatment of the monthly accumulated precipitation amount, the SmirnovGrubbs test for Ratio was applied to discard outliers. If at least 9 months were available, the annual accumulated precipitation was calculated.

These observation datasets taken from EANET, JMA, and CRIEPI were essentially the same as those used in our previous studies (Itahashi et al., 2014a, 2015). A limitation of our previous studies was a lack of spatial coverage over northern China, especially around the capital of Beijing because EANET covered only the area from southern to central China (Fig. 1). It has been recognized that anthropogenic emissions centered over this region (Kurokawa et al., 2013; Li et al., 2017), the related atmospheric concentration, and depositions are severe in China. To overcome this limitation and advance our knowledge of precipitation chemistry over the whole of China, we evaluated additional sources of data for the chemical concentration of precipitation over China.

The Integrated Monitoring Program on Acidification of the Chinese Terrestrial System (IMPACTS) was established through a Chinese-Norwegian cooperative project (Larssen et al., 2004, 2006) from 2001 to 2003. Under the IMPACTS program, atmospheric concentration, precipitation composition, and soil, water, and vegetative effects were studied at five forested sites (LXH, LGC, LCG, CJT, and TSP; refer to Fig. 1 and Table 1) over southern China. In terms of deposition, four measurements (wet-only, bulk, throughfall collected below the tree canopy, and belowground vegetation) were obtained. Wet-only sampling data were used in this study. Observations of the chemical composition of precipitation by a wet-only sampler were reported for four sites (LGS, LCG, CJT, and TSP) from 2001 to 2003 and for one site (LXH) from 2002 to 2003. Data for LGS in 2001 were not used, owing to insufficient coverage. At TSP, continuous monitoring results up to 2013 have recently been reported (Yu et al., 2017).

The precipitation chemistry over northern China has important implications. The precipitation sample at Beijing Normal University (BNU) in 2003 (Sun et al., 2004; Tang et al., 2005) and the recent work by the State Key Laboratory of Atmospheric Boundary Layer Physics and Atmospheric Chemistry/Institute of Atmospheric Physics/Chinese Academy of Sciences (LAPC/IAP/CAS) from December 2007 to November 2010 (Pan et al., 2012, 2013; Pan and Wang, 2015; Wang et al., 2012) were included in this study. Using the observation framework from BNU, data for a total of 53 rain events were collected at Beijing. To prevent contamination from dry deposition, the collector surface was covered with a plastic lid. A detailed description of this collection method is provided by Tang et al. (2005). In the recent work conducted by LAPC/IAP/CAS, a 3-year observation from December 2007 to November 2010 was conducted at 10 sites around Beijing. Daily rainwater samples were collected using a customized wet/dry automatic collector. The precipitation sensor opened the collection funnel of the cover device when rainfall began. In this study, December 2007 to November 2008 was regarded as the year 2008, December 2008 to November 2009 was regarded as the year 2009, and December 2009 to November 2010 was regarded as the year 2010. For the IMPACTS and LAPC/IAP/CAS datasets, the $n s s-\mathrm{SO}_{4}^{2-}$ concentration was calculated using $\mathrm{Na}^{+}$as a sea salt tracer based on Eq. (1). Owing to the lack of information on $\mathrm{Na}^{+}$within the samples at $\mathrm{BNU}, \mathrm{SO}_{4}^{2-}$ was used; however, it was reported that $\mathrm{Na}^{+}$is not a major ion component of these samples.

\subsection{Emission inventories}

It is predicted that variation in $\mathrm{NO}_{3}^{-}, \mathrm{SO}_{4}^{2-}$, and hence $\mathrm{Ra}$ tio is directly related to the emission of $\mathrm{NO}_{x}$ and $\mathrm{SO}_{2}$. We used the following emission inventories in this study. The Regional Emission inventory in ASia (REAS) version 2.1 (Kurokawa et al., 2013), which covers Asia from 2000 to 2008, was the main dataset used in this study to obtain $\mathrm{NO}_{x}$ and $\mathrm{SO}_{2}$ emissions over China, Korea, and Japan. The recent status of Asian anthropogenic emissions was assessed by harmonizing different local emission inventories with a mosaic approach named MIX (Li et al., 2017). MIX covers the years 2008 and 2010. The data from MIX were also used to acquire data for $\mathrm{NO}_{x}$ and $\mathrm{SO}_{2}$ emissions over China, Korea, and Japan.

The latest country-level status of emissions in China is described by Xia et al. (2016). Their emissions data cover the period from 2000 to 2014 . The primary case, which analyzed the contributions of advanced combustors with improved energy efficiency and air pollutant control devices with improved pollutant removal efficiency, was used in this study. In Korea, the National Institute of Environmental Re- 
search (NIER) provided estimates of the national emissions via the National Air Pollutants Emission Service, and the latest data reported cover 1999 to 2013 (NIER, 2017). In Japan, the Japan Auto-Oil Program (JATOP) provided 5-year interval emission datasets beginning in 1995 (JATOP, 2012a, b). The datasets for 2005 and 2010 were used in this study.

Using the total amounts of $\mathrm{NO}_{x}$ and $\mathrm{SO}_{2}$ emissions estimated via inventories over China, Korea, and Japan, the $\mathrm{NO}_{x} / \mathrm{SO}_{2}$ emission ratio on a molar basis was calculated by calculating $\mathrm{NO}_{x}$ as $\mathrm{NO}_{2}$. The behavior of the $\mathrm{NO}_{x} / \mathrm{SO}_{2}$ emissions ratio is correlated to Ratio in precipitation.

\subsection{Satellite observations}

The emission inventories had some time lags. Accordingly, satellite observations of the $\mathrm{NO}_{2}$ and $\mathrm{SO}_{2}$ vertical column density were combined to capture the recent status of $\mathrm{NO}_{x}$ and $\mathrm{SO}_{2}$. The $\mathrm{NO}_{x} / \mathrm{SO}_{2}$ column ratio reflects the $\mathrm{NO}_{x} / \mathrm{SO}_{2}$ emission ratio and was effective for characterizing the correspondence with Ratio in precipitation. Recently, satellite observations have been widely used as a proxy for emissions data. The $\mathrm{NO}_{2}$ column has been used to capture $\mathrm{NO}_{x}$ emissions (e.g., Miyazaki et al., 2012; Mijling et al., 2013; Itahashi et al., 2014b; Han et al., 2015; Irie et al., 2016), and the $\mathrm{SO}_{2}$ column has been used for $\mathrm{SO}_{2}$ emissions (e.g., Lee et al., 2011; Li et al., 2010) and/or volcanic eruptions (e.g., Brenot et al., 2014). Several studies have indicated the importance of different technologies to control emissions (e.g., Li et al., 2010; Wang et al., 2015; Krotkov et al., 2016; van der A et al., 2017). For example, the ratio of Ozone Monitoring Instrument (OMI)-derived $\mathrm{SO}_{2} / \mathrm{NO}_{2}$ was used to determine the effectiveness of the flue-gas desulfurization devices for power plants in China ( $\mathrm{Li}$ et al., 2010; Wang et al., 2015).

The $\mathrm{NO}_{2}$ and $\mathrm{SO}_{2}$ column dataset, which was observed by OMI onboard the National Aeronautics and Space Administration (NASA) Earth Observing System Aura satellite, was used in this study (NASA, 2017). The Aura satellite was launched on 15 July 2004 in a sun-synchronous ascending polar orbit with a local equator crossing time of 13:45. During the data period, it measured sunlight backscattered from the Earth over a wide range of ultraviolet and visible wavelengths to derive abundances of ozone and other trace gases important for air quality and climate. Science-quality data operations began on 1 October 2004; hence, the data from 2005 to 2015 were used to cover our analysis period of 20012015. Retrieval algorithms were based on the products provided by NASA.

In terms of the $\mathrm{NO}_{2}$ column, we used the most recent version of level 3 daily global nitrogen dioxide product (OMNO2d) of version 3.0, which was released in August 2016 and is gridded at a resolution of $0.25^{\circ} \times 0.25^{\circ}$ (Krotkov, 2013; Krotkov et al., 2017). This product contains the total and tropospheric column for all atmospheric conditions and for sky conditions where the cloud fraction is less than $30 \%$.
We analyzed the tropospheric column with clouds screened on the condition of a cloud fraction of less than $30 \%$.

In terms of the $\mathrm{SO}_{2}$ column, we used a level 3 daily global sulfur dioxide product (OMSO2e) of the latest version (3.0), which was released in February 2015 and is gridded at a resolution of $0.25^{\circ} \times 0.25^{\circ}$ (Krotkov et al., 2015). The dataset contains the total column of $\mathrm{SO}_{2}$ in the planetary boundary layer (PBL). The algorithm was based on a principal component analysis, as introduced by $\mathrm{Li}$ et al. (2013). Cloud fraction, scene number, solar and satellite viewing angles, and row anomaly flags were provided as ancillary parameters. The data filtering of this level 3 dataset included the removal of rows with any of the following: anomaly flags, radiative cloud fraction greater than $20 \%$, solar zenith angle greater than $70.0^{\circ}$, or scene number greater than 58 or less than 3. In addition, we adopted the smoothed method to average out the noise levels of the $\mathrm{SO}_{2}$ column, following the research of Koukouli et al. (2016), who provided the anthropogenic loading of $\mathrm{SO}_{2}$ over China as obtained from different satellite sensors. This method smoothed the $\mathrm{SO}_{2}$ column assigned to each of the $0.25^{\circ} \times 0.25^{\circ}$ grid cells, which were weighted by the $\mathrm{SO}_{2}$ column of the surrounding eight cells. In this process, the negative values were regarded as zero values because our aim was to construct the $\mathrm{NO}_{x} / \mathrm{SO}_{2}$ column ratio from satellite observations. Two data periods associated with volcanic activities were excluded from our analysis as follows. The Sarychev Volcano in the Kuril Islands $\left(48.09^{\circ} \mathrm{N}, 153.20^{\circ} \mathrm{E}\right) \mathrm{had}$ an explosive eruption that emitted a huge amount of ash and $\mathrm{SO}_{2}$ at altitudes of $10-16 \mathrm{~km}$ (Brenot et al., 2014). The data from 14 to 22 June 2009 included this large amount of $\mathrm{SO}_{2}$ (over 10 D.U.) in and around the analyzed domain; accordingly, they were discarded from the calculations of monthly and annual means. An eruption of the Nabro Volcano in Eritrea $\left(13.37^{\circ} \mathrm{N}, 41.07^{\circ} \mathrm{E}\right)$ from 12 June to 7 July 2011 was also reported. During the night of 12 June 2011, this volcano started to erupt, and on 14 June 2011, it spewed a volcanic plume across the route of many flights over east Africa and the Middle East (Brenot et al., 2014). The data from 15 June to 9 July 2011 were excluded from the calculations of monthly and annual means according to the approach detailed in van der A et al. (2017). In Japan, where many active volcanoes are located, $\mathrm{SO}_{2}$ was continuously emitted at a level that surpassed anthropogenic emissions (e.g., Itahashi et al., 2017a). Owing to the difficulties of attempting to separate the effect of volcanic activity, the $\mathrm{SO}_{2}$ column data for Japan, excluding the two data periods mentioned above, were used.

Based on the daily gridded data of $\mathrm{NO}_{2}$ and $\mathrm{SO}_{2}$ columns, monthly averages were calculated first and then the annual averages were calculated. In the calculation of annual averages, cells with monthly averaged data not available for at least 9 months were regarded as deficient cells for consistency with the criteria adopted for the ground-based observations of $\mathrm{NO}_{3}^{-}$, nss- $\mathrm{SO}_{4}^{2}$, and Ratio in precipitation. The 
$\mathrm{NO}_{x} / \mathrm{SO}_{2}$ column ratio was obtained from the annual averaged gridded data for $\mathrm{NO}_{2}$ and $\mathrm{SO}_{2}$ columns.

\section{Results and discussion}

\subsection{Long-term trend in the chemical composition of precipitation with respect to emissions}

The long-term trends in the precipitation amount, $\mathrm{NO}_{x}$ emission from $\mathrm{NO}_{2}$ columns, $\mathrm{NO}_{3}^{-}$concentration in precipitation, $\mathrm{SO}_{2}$ emission from $\mathrm{SO}_{2}$ columns, and nss- $\mathrm{SO}_{4}^{2-}$ concentration in precipitation in 2001-2015 over China, Korea, and Japan are shown in Fig. 2. The averaged values and statistical analyses to estimate linear trends during Phase I (20012005), II (2006-2010), and III (2011-2015) are summarized in Table 2. Linear trends during each of the three phases were analyzed using linear regression, and significance levels were calculated using Student's $t$ test. To support our finding of variation in the spatial distribution, satellite observations from 2005 to 2015 were used. $\mathrm{NO}_{2}$ and $\mathrm{SO}_{2}$ columns were mapped for 2006-2007 (the first half of Phase II), 2010-2011 (the transition from Phase II to Phase III), and 2014-2015 (the latter half of Phase III), as shown in Fig. 3. The annual variation in $\mathrm{NO}_{2}$ and $\mathrm{SO}_{2}$ columns, based on linear regression analyses during phases II and III, are also mapped in Fig. 4.

As shown in Fig. 2a, year-to-year variation in precipitation was found and the average values for annual precipitation accumulation were around 1300,1100 , and $1500 \mathrm{~mm} \mathrm{yr}^{-1}$ over China, Korea, and Japan, respectively. A statistical analysis revealed that, except for the increasing and decreasing trends over China and Korea during Phase III $(p<0.05)$, there were no clear changes in precipitation levels during the 15-year period.

The $\mathrm{NO}_{x}$ emissions and satellite observations of $\mathrm{NO}_{2}$ columns are shown in Fig. 2b. Over China, emissions increased from 2001 to 2010, peaked in 2011-2012, and decreased after 2012, consistent with previous findings (e.g., Irie et al., 2016; Krotkov et al., 2016; van der A et al., 2017). Based on the spatial distribution, the $\mathrm{NO}_{2}$ column above China peaked during the transition from Phase II and III (left panel of Fig. 3b) and contrasting trends, that is, increasing and decreasing trends, were revealed during phases II and III (left panel of Fig. 4a and b). Over China, the $\mathrm{NO}_{x}$ emissions of REAS and Xia et al. (2016) as well as satellite observations of $\mathrm{NO}_{2}$ columns were highly consistent over long-term observations. Over Korea, $\mathrm{NO}_{x}$ emissions obtained from REAS and NIER showed a slight increase in 2003-2004 and a flat trend after 2008. There were some inconsistencies between $\mathrm{NO}_{x}$ emissions and the $\mathrm{NO}_{2}$ column in 2005-2007. On the one hand, $\mathrm{NO}_{x}$ emissions showed a decreasing trend; on the other hand, the $\mathrm{NO}_{2}$ column showed a flat trend. Over Japan, both $\mathrm{NO}_{x}$ emissions and the $\mathrm{NO}_{2}$ column exhibited a slight decrease during the 15 -year period. Overall, the cor- relation between $\mathrm{NO}_{x}$ emissions and $\mathrm{NO}_{2}$ columns suggests that satellite observations of the $\mathrm{NO}_{2}$ column can serve as a proxy for $\mathrm{NO}_{x}$ emissions.

Such variation in $\mathrm{NO}_{x}$ emissions should be related to the change in the $\mathrm{NO}_{3}^{-}$concentration in precipitation. The long-term trend in the $\mathrm{NO}_{3}^{-}$concentration in precipitation is shown in Fig. 2c. The $\mathrm{NO}_{3}^{-}$concentration in precipitation decreased in the order of China, Korea, Japan, with concentrations of approximately $50 \mu \mathrm{eq} \mathrm{L}^{-1}$ in China and $40 \mu \mathrm{eq} \mathrm{L}^{-1}$ in Korea. These levels were around 2-fold greater than that in Japan $\left(15-20 \mu \mathrm{eq} \mathrm{L}^{-1}\right)$. The temporal variation found in the $\mathrm{NO}_{3}^{-}$concentration in precipitation did not correspond to the variation in $\mathrm{NO}_{x}$ emissions (Fig. 2b). This was particularly notable for China; although $\mathrm{NO}_{x}$ emissions from 2001 to 2010 doubled, the $\mathrm{NO}_{3}^{-}$concentration in precipitation did not increase substantially. The $\mathrm{NO}_{3}^{-}$concentration in precipitation over Korea and Japan also did not show dramatic variation. This may be explained by changes in atmospheric composition and chemical regimes with changes in base cations and the oxidation capacity of the atmosphere, leading to changes in the lifetime of nitrogen species. Statistical analyses of the $\mathrm{NO}_{3}^{-}$concentration in precipitation (Table 2) did not indicate a significant overall trend for phases I-III, with values remaining within -5 to $+3 \% \mathrm{yr}^{-1}$ over China, Korea, and Japan, with the exception of a negative trend of $-3.4 \pm 1.3 \% \mathrm{yr}^{-1}(p<0.05)$ in Japan during Phase II. When comparing EANET observations with additional datasets, IMPACTS sites around south China showed lower $\mathrm{NO}_{3}^{-}$concentrations in precipitation, reflecting the characteristics of remote sites, while BNU and LAPC/IAP/CAS sites around Beijing showed relatively high concentrations, reflecting the emission intensity over northern China. These levels reflected the emission intensity of the particular regions and were nearly within 1 standard deviation of values obtained from the EANET observation network. For China, 10 EANET sites were classified as belonging to an urban category (six sites) and rural and remote sites (four sites) (Fig. 2c, see Table 1 for classification). Generally, concentrations were higher for urban sites than for rural and remote sites, and the correlation coefficient for mean values over urban sites and rural and remote sites was 0.21 ; these results can be attributed to differences in regional characteristics.

$\mathrm{SO}_{2}$ emissions and satellite observations of the $\mathrm{SO}_{2}$ column are shown in Fig. 2d. Over China, a steady increase was detected for 2001-2004, with a peak in 2005-2006 and a decrease after 2006; there thus seems to be a 5-year time lag prior to the decrease in $\mathrm{NO}_{x}$ emissions and $\mathrm{NO}_{2}$ columns. The $\mathrm{SO}_{2}$ column, which was available from 2005, showed a continuous decline over all of China (center of Fig. 3) and a decreasing trend was estimated by linear regression (center of Fig. 4a and b). In China, the $\mathrm{SO}_{2}$ emissions of REAS and $\mathrm{Xia}$ et al. (2016) and $\mathrm{SO}_{2}$ columns were highly consistent with the observed variation. Over Korea, $\mathrm{SO}_{2}$ emissions obtained from REAS and NIER showed a slight de- 
(i) China

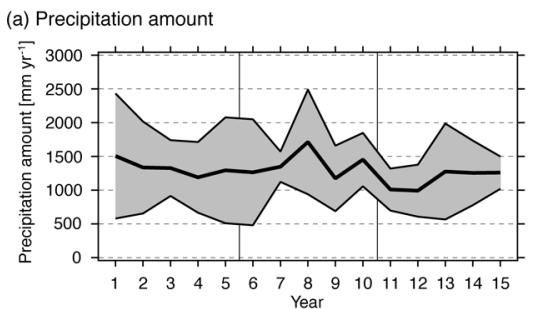

(b) NOx emission and $\mathrm{NO}_{2}$ column

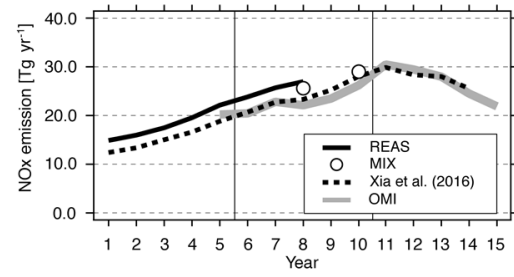

(c) $\mathrm{NO}_{3}{ }^{-}$concentration in precipitation

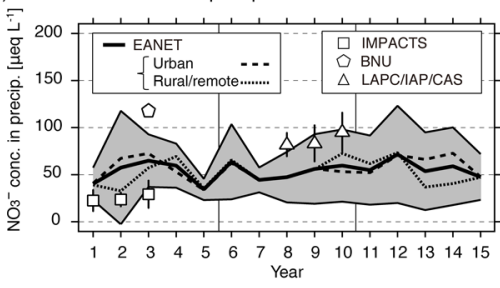

(d) $\mathrm{SO}_{2}$ emission and $\mathrm{SO}_{2}$ column

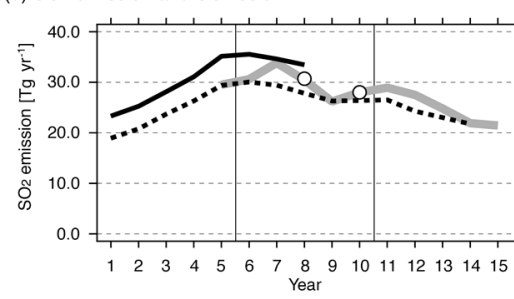

(e) nss- $\mathrm{SO}_{4}{ }^{2-}$ concentration in precipitation

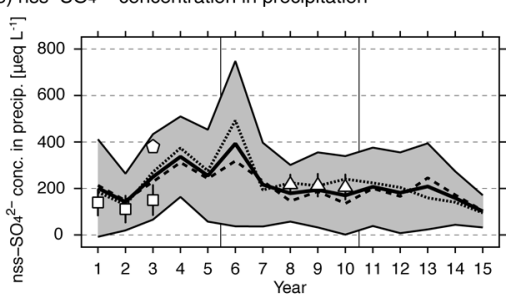

(ii) Korea

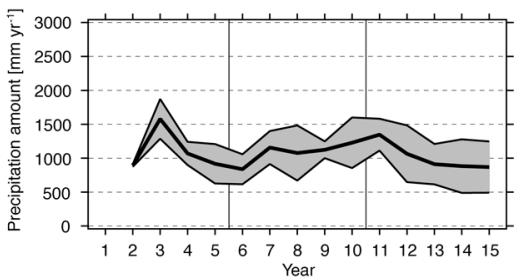

Year
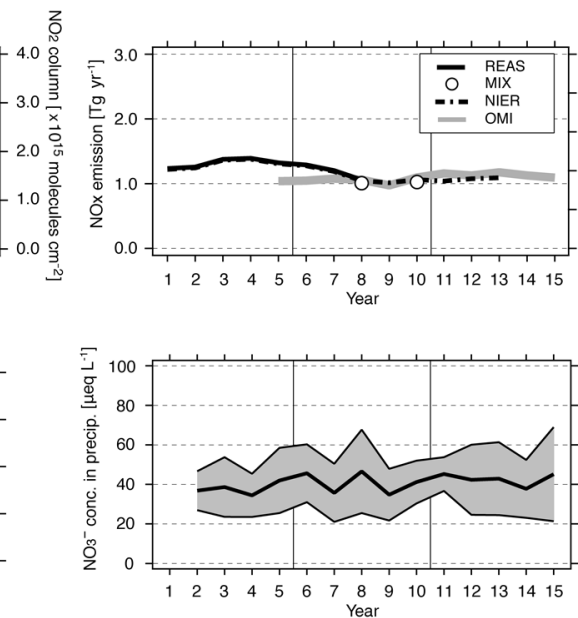

Year
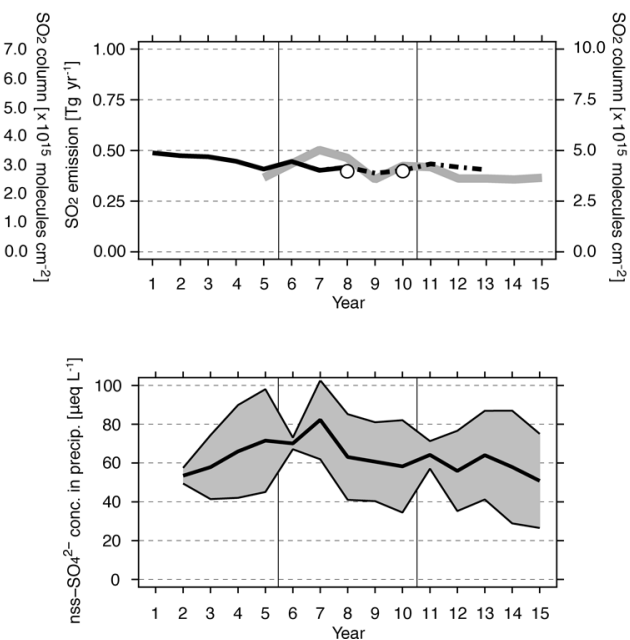

(iii) Japan

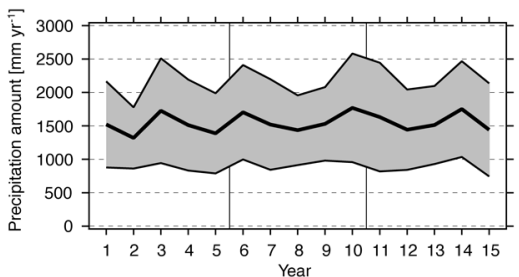

Year
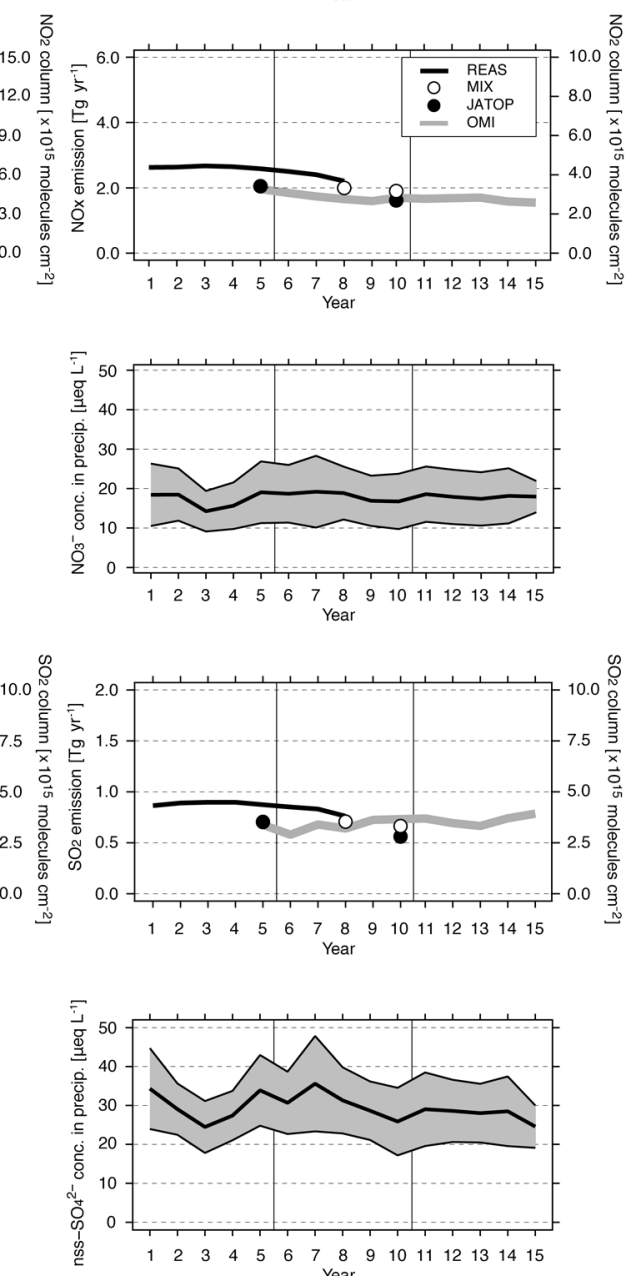

Year

Figure 2. Long-term temporal variation in (a) precipitation, (b) $\mathrm{NO}_{x}$ emission with the $\mathrm{NO}_{2}$ column, (c) $\mathrm{NO}_{3}^{-}$concentration in precipitation, (d) $\mathrm{SO}_{2}$ emission with the $\mathrm{SO}_{2}$ column, and (e) nss- $\mathrm{SO}_{4}^{2-}$ concentration in precipitation during 2001-2015 over (i) China, (ii) Korea, and (iii) Japan. Mean and 1 standard deviation across EANET observation sites (JMA and CRIEPI sites are also included in Japan) are indicated by the thick lines and shaded areas, respectively, in (a, c, e). For China, EANET observation sites are denoted with dashed lines for urban sites and dotted lines for rural and remote sites, and observation campaign data are indicated by marks corresponding to marks on Fig. 1. The numbers at the bottom indicate the number of years after 2000 (e.g., 5 indicates 2005 and 10 indicates 2010).

crease, which was consistent with the $\mathrm{SO}_{2}$ column reduction, but some discrepancies were found for 2007-2008. The temporal variation in the $\mathrm{SO}_{2}$ column in Korea was similar to that observed in China. The spatial distribution data (Fig. 3) suggested that the $\mathrm{SO}_{2}$ column over Korea is impacted by upwind regions, e.g., China. The $\mathrm{SO}_{2}$ column obtained from $\mathrm{SO}_{2}$ PBL products has a center of mass altitude at about $900 \mathrm{~m}$, which is expected to lead to longer transport distances and longer lifetimes of $\mathrm{SO}_{2}$. Therefore, compared with the correlation between $\mathrm{NO}_{x}$ emission and $\mathrm{NO}_{2}$ columns, it was difficult to clearly capture the relation between $\mathrm{SO}_{2}$ emissions and $\mathrm{SO}_{2}$ columns. Over Japan, $\mathrm{SO}_{2}$ emissions exhibited a slight decrease during the 15-year period, whereas a nearly flat trend was found for the $\mathrm{SO}_{2}$ col- 
(a) Averaged between 2006 and 2007 (the first half of Phase II)
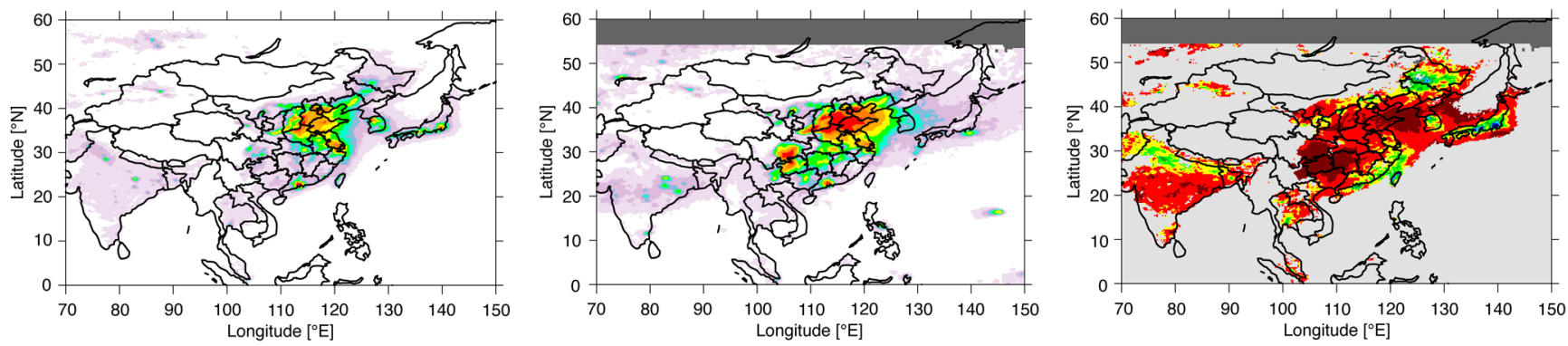

(b) Averaged between 2010 and 2011 (transition between Phase II and Phase III)
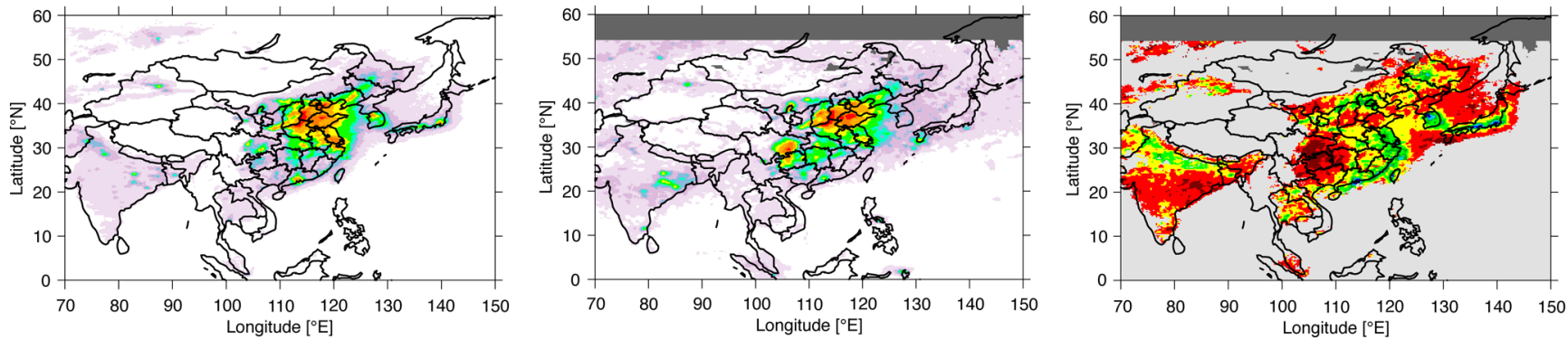

(c) Averaged between 2014 and 2015 (the latter half of Phase III)

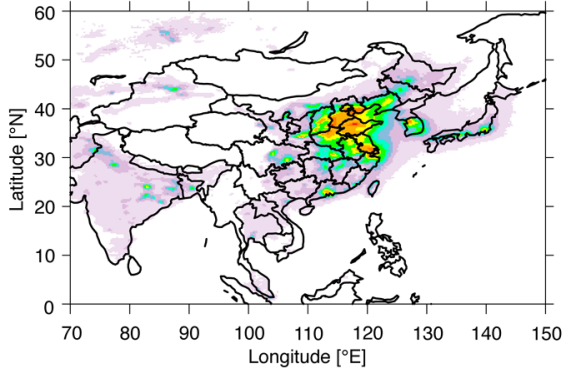

$\begin{array}{lllllllll}1.0 & 2.0 & 3.0 & 4.0 & 5.0 & 7.5 & 10.0 & 15.0 & 20.0\end{array}$ $\mathrm{NO}_{2}$ vertical column density $\left[\times 10^{15}\right.$ molecules $\left.\mathrm{cm}^{-2}\right]$

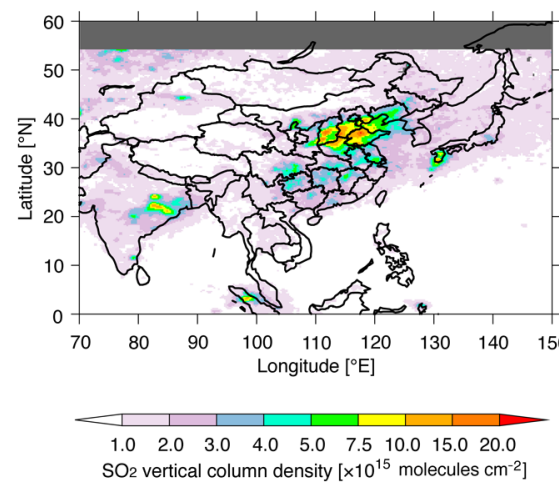

Figure 3. Satellite observations of the (left) $\mathrm{NO}_{2}$ column, (center) $\mathrm{SO}_{2}$ column, and (right) $\mathrm{NO}_{2} / \mathrm{SO}_{2}$ column ratio averaged over (a) 2006-2007 (the first half of Phase II), (b) 2010-2011 (transition between Phase II and Phase III), and (c) 2014-2015 (the latter half of Phase III). Dark-gray cells indicate places where annual mean could not be calculated. If either the $\mathrm{NO}_{2}$ or $\mathrm{SO}_{2}$ column value is less than $1.0 \times 10^{15}$ molecules $\mathrm{cm}^{-2}$, this is indicated by a light-gray cell to clarify the $\mathrm{NO}_{2} / \mathrm{SO}_{2}$ column ratio.

umn. This is partially related to the fact that the $\mathrm{SO}_{2}$ column includes $\mathrm{SO}_{2}$ emissions from volcanoes. Hot spots of the $\mathrm{SO}_{2}$ column above south Kyushu (a western island of Japan) and central Honshu (near Tokyo), shown in Fig. 3, were related to the location of volcanic activity during this period.

The nss- $\mathrm{SO}_{4}^{2-}$ concentration in precipitation also decreased in the order of China, Korea, and Japan, similar to the $\mathrm{NO}_{3}^{-}$concentration in precipitation. The nss- $\mathrm{SO}_{4}^{2-}$ concentration in precipitation was $200-400 \mu \mathrm{eq} \mathrm{L}^{-1}$ above China, around $60 \mu \mathrm{eq} \mathrm{L}^{-1}$ above Korea, and $30 \mu \mathrm{eq} \mathrm{L}^{-1}$ above Japan. The levels over China were about 10 -fold greater than those over Japan, and the levels over Korea were almost twice those over Japan (Fig. 2e). $\mathrm{SO}_{2}$ emissions from China reached a peak in 2005-2006 (Fig. 2d), and the nss- $\mathrm{SO}_{4}^{2-}$ concentration in precipitation above China reached approximately $393.0 \mu \mathrm{eq} \mathrm{L} \mathrm{L}^{-1}$ in 2006 , with a decline in 2015. The nss- $\mathrm{SO}_{4}^{2-}$ concentrations in precipitation above China were around $230 \mu \mathrm{eq} \mathrm{L}^{-1}$ during Phase I and II but were $171.5 \mu \mathrm{eq} \mathrm{L}^{-1}$ during Phase III (Table 2). Trends calculated by linear regression were $12.7 \pm 8.3 \% \mathrm{yr}^{-1}$ (not significant) during Phase I, $-20.3 \pm 8.8 \% \mathrm{yr}^{-1}$ (not significant) during Phase II, and $-13.6 \pm 5.2 \% \mathrm{yr}^{-1}(p<0.05)$ during Phase III. It seems that the variation in the nss- $\mathrm{SO}_{4}^{2-}$ concentration in precipitation was partially related to $\mathrm{SO}_{2}$ emission changes. In comparing EANET observations with other datasets, IMPACTS sites around south China showed lower nss- $\mathrm{SO}_{4}^{2-}$ concentrations in precipitation, BNU sites showed higher concentrations, and LAPC/IAP/CAS sites showed similar values. These levels were within 1 standard devia- 
Table 2. Statistical analysis of average values and linear trends for precipitation, $\mathrm{NO}_{3}^{-}$concentration in precipitation, and nss-SO ${ }_{4}^{2-}$ concentration in precipitation over China, Korea, and Japan during phases I, II, and III.

\begin{tabular}{|c|c|c|c|c|c|c|}
\hline & \multicolumn{2}{|c|}{ Phase I (2001-2005) } & \multicolumn{2}{|c|}{ Phase II (2006-2010) } & \multicolumn{2}{|c|}{ Phase III (2011-2015) } \\
\hline & Mean & Trend & Mean & Trend & Mean & Trend \\
\hline \multicolumn{7}{|c|}{ Precipitation $\left(\mathrm{mm} \mathrm{yr}^{-1}\right)$} \\
\hline China & $1330.2(N=35)$ & $-4.3 \pm 1.9$ & $1390.2(N=31)$ & $+1.5 \pm 5.4$ & $1158.3(N=28)$ & $+6.6 \pm 2.5^{\mathrm{a}}$ \\
\hline Korea & $1114.9(N=11)$ & $-3.9 \pm 15.4$ & $1084.3(N=15)$ & $+6.9 \pm 3.0$ & $1015.1(N=15)$ & $-11.2 \pm 3.3^{\mathrm{a}}$ \\
\hline Japan & $1493.5(N=44)$ & $-0.5 \pm 3.8$ & $1591.7(N=56)$ & $+0.9 \pm 3.2$ & $1555.7(N=56)$ & $-0.5 \pm 3.1$ \\
\hline \multicolumn{7}{|c|}{$\mathrm{NO}_{3}^{-}$concentration in precipitation $\left(\mu \mathrm{eq} \mathrm{L}^{-1}\right)$} \\
\hline China & $51.3(N=31)$ & $-1.9 \pm 9.4$ & $54.3(N=31)$ & $+0.6 \pm 5.5$ & $57.3(N=34)$ & $-4.7 \pm 5.0$ \\
\hline Korea & $38.0(N=11)$ & $+3.0 \pm 4.1$ & $40.8(N=15)$ & $-2.4 \pm 4.7$ & $42.7(N=15)$ & $-1.1 \pm 2.5$ \\
\hline Japan & $17.2(N=44)$ & $-0.9 \pm 4.4$ & $18.1(N=55)$ & $-3.4 \pm 1.3^{\mathrm{a}}$ & $18.0(N=55)$ & $-0.6 \pm 0.8$ \\
\hline \multicolumn{7}{|c|}{ nss- $\mathrm{SO}_{4}^{2-}$ concentration in precipitation $\left(\mu \mathrm{eq} \mathrm{L}^{-1}\right)$} \\
\hline China & $237.0(N=32)$ & $+12.7 \pm 8.3$ & $230.6(N=32)$ & $-20.3 \pm 8.8$ & $171.5(N=33)$ & $-13.6 \pm 5.2^{\mathrm{a}}$ \\
\hline Korea & $62.2(N=11)$ & $+10.0 \pm 0.8^{\mathrm{c}}$ & $66.9(N=15)$ & $-6.8 \pm 3.6$ & $58.6(N=15)$ & $-4.2 \pm 2.6$ \\
\hline Japan & $29.8(N=44)$ & $-0.8 \pm 5.2$ & $30.4(N=56)$ & $-5.4 \pm 2.9$ & $27.8(N=55)$ & $-3.3 \pm 1.5$ \\
\hline
\end{tabular}

Note: total number of observation sites are shown in parentheses. Linear trends were estimated using linear regression and are shown as rates $\left(\% \mathrm{yr}^{-1}\right)$. Significance levels are indicated by ${ }^{\mathrm{a}} p<0.05,{ }^{\mathrm{b}} p<0.01$, and ${ }^{\mathrm{c}} p<0.001$, and lack of a mark indicates a lack of significance. Analysis for Korea during Phase I was for the 2002-2005 period.

(a) Annual changes between 2006 and 2010 (Phase II)
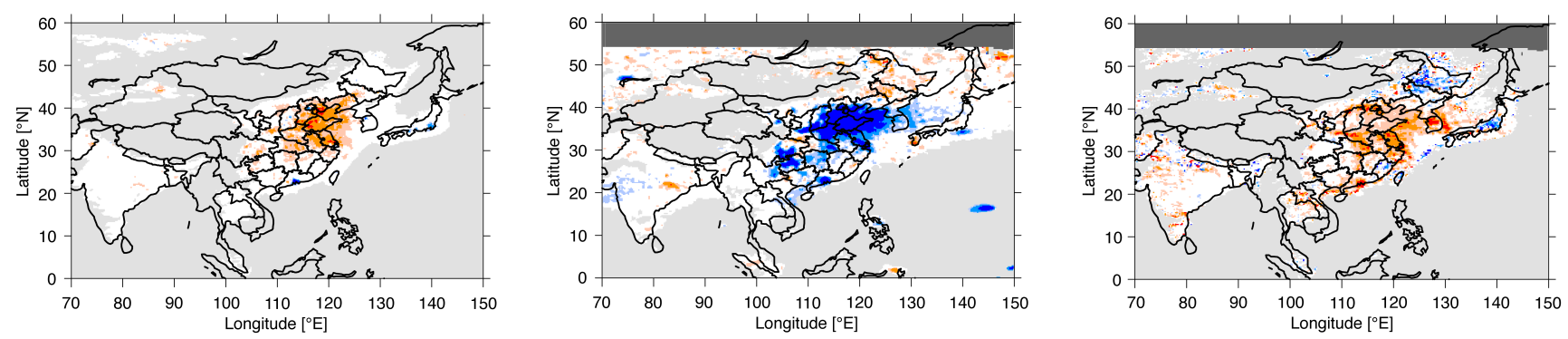

(b) Annual changes between 2011 and 2015 (Phase III)
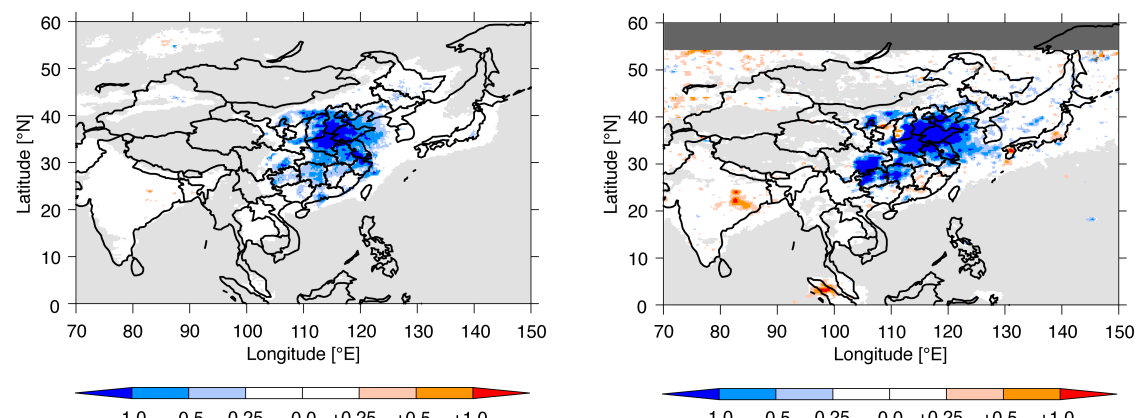

$\begin{array}{lllllll}-1.0 & -0.5 & -0.25 & 0.0 & +0.25 & +0.5 & +1.0\end{array}$

Change in $\mathrm{NO}_{2}$ vertical column density $\left[\times 10^{15}\right.$ molecules $\left.\mathrm{cm}^{-2} \mathrm{yr}^{-1}\right]$

Change in $\mathrm{SO}_{2}$ vertical column density $\left[\times 10^{15}\right.$ molecules $\left.\mathrm{cm}^{-2} \mathrm{yr}^{-1}\right]$

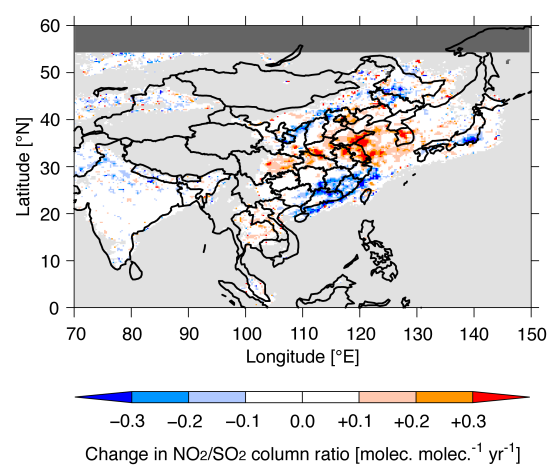

Figure 4. Annual changes based on the linear regression results for the (left) $\mathrm{NO}_{2}$ column, (center) $\mathrm{SO}_{2}$ column, and (right) $\mathrm{NO}_{2} / \mathrm{SO}_{2}$ column ratio during (a) Phase II and (b) Phase III. Dark-gray cells indicate areas where annual mean calculation could not be performed. If either the $\mathrm{NO}_{2}$ or $\mathrm{SO}_{2}$ column value is less than $1.0 \times 10^{15}$ molecules $\mathrm{cm}^{-2}$, this is indicated by a light-gray cell for clarity. 
(i) China

(a) $\mathrm{NO} x / \mathrm{SO}_{2}$ emission ratio and $\mathrm{NO}_{2} / \mathrm{SO}_{2}$ column ratio

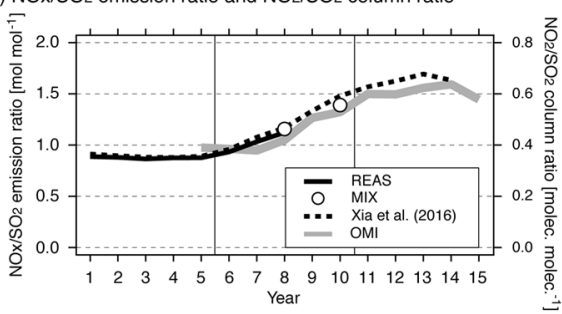

(b) $\mathrm{NO}_{3}{ }^{-} / \mathrm{nss}^{-} \mathrm{SO}_{4}{ }^{2-}$ concentration ratio in precipitation

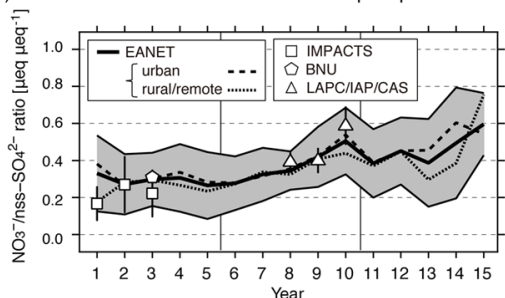

Year (ii) Korea
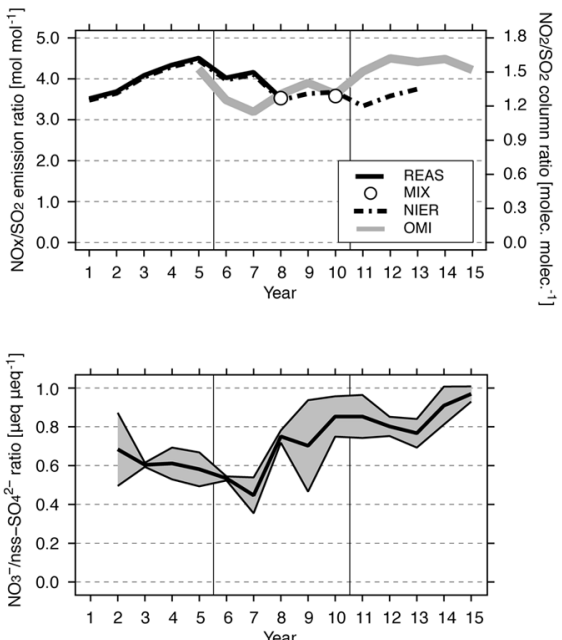

(iii) Japan
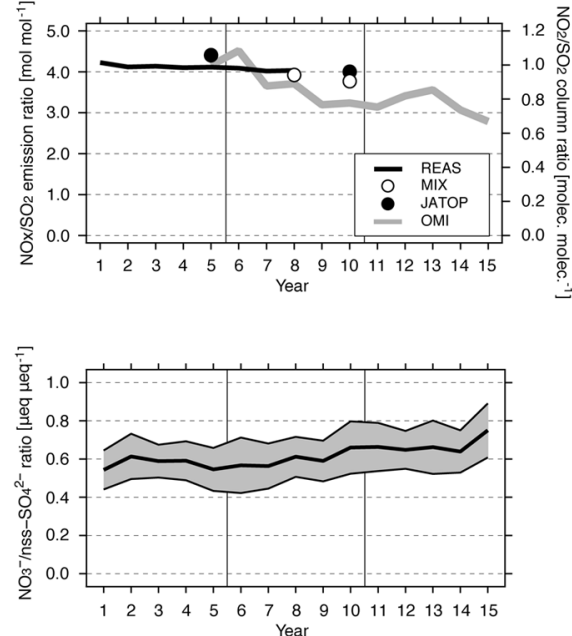

Figure 5. Long-term temporal variation in the (a) $\mathrm{NO}_{x} / \mathrm{SO}_{2}$ emission ratio and $\mathrm{NO}_{2} / \mathrm{SO}_{2}$ column ratio and (b) $\mathrm{NO}_{3}^{-} / \mathrm{nss}^{-\mathrm{SO}_{4}^{2-}}$ concentration in precipitation (Ratio) during 2001-2015 over (i) China, (ii) Korea, and (iii) Japan. Mean and 1 standard deviation across EANET observation sites (JMA and CRIEPI sites are also included in Japan) are indicated by the thick lines and shaded areas, respectively, in (b). For China, EANET observation sites are denoted with dashed lines for urban sites and dotted lines for rural and remote sites, and observation campaign data are indicated by marks corresponding to Fig. 1. The numbers at the bottom indicate the number of years after 2000 (e.g., 5 indicates 2005 and 10 indicates 2010).

tion of the means obtained from the EANET observation network, similar to the $\mathrm{NO}_{3}^{-}$concentration in precipitation. By classifying 10 EANET sites over China as urban sites or rural and remote sites (Fig. 2e; see Table 1 for classification), the mean values over urban sites and rural and remote sites were highly correlated, with a correlation coefficient of 0.78 . This result implied that the nss- $\mathrm{SO}_{4}^{2-}$ concentration in precipitation was largely determined by large-scale characteristics related to $\mathrm{SO}_{2}$ emissions. Variation in $\mathrm{SO}_{2}$ emission from Korea and Japan was constant or declined between 2000 and 2008 , and the nss- $\mathrm{SO}_{4}^{2-}$ concentration in precipitation above Korea and Japan did not exhibit a clear relation with $\mathrm{SO}_{2}$ emissions in these countries. In addition, the increasing trend of $+10.0 \pm 0.8 \% \mathrm{yr}^{-1}(p<0.001)$ over Korea during Phase I was not related to the variation in $\mathrm{SO}_{2}$ emissions in Korea. Relatively high nss- $\mathrm{SO}_{4}^{2-}$ concentrations in precipitation in Japan in 2001-2002 were partially explained by the $\mathrm{SO}_{2}$ emissions from the Miyake-jima volcano in 2000 (Itahashi et al., 2012, 2014a, 2015). With the exception of an increase in Korea during Phase I and the peak in Japan in 2001-2002, nss-SO ${ }_{4}^{2-}$ concentrations in precipitation above Korea and Japan were high in 2005-2007 and subsequently decreased. These patterns were similar to those over China and appeared to be connected to the variation in $\mathrm{SO}_{2}$ emissions from China, though these trends were not significant.

\subsection{Long-term trend in Ratio in precipitation and its relationship to changes in emissions in China}

The long-term variation in precipitation and $\mathrm{NO}_{3}^{-}$and nss$\mathrm{SO}_{4}^{2-}$ concentrations in precipitation did not indicate clear or significant trends during the 15 -year period above China, Korea, and Japan, with a few exceptions. To further clarify the correlations between anthropogenic emission changes and the precipitation chemistry over East Asia, we focus on Ratio. The long-term trends in Ratio were analyzed for 20012015, and the results are shown in Fig. 5. The $\mathrm{NO}_{x} / \mathrm{SO}_{2}$ emission ratio and $\mathrm{NO}_{2} / \mathrm{SO}_{2}$ column ratio were calculated using average values over each country. Over China, both the $\mathrm{NO}_{x} / \mathrm{SO}_{2}$ emission ratio and $\mathrm{NO}_{2} / \mathrm{SO}_{2}$ column ratio were flat during Phase I, sharply increased during Phase II, and were nearly flat during Phase III. The substantial increase during Phase II was caused by an increase in $\mathrm{NO}_{x}$ emissions and a decrease in $\mathrm{SO}_{2}$ emissions (Fig. $2 \mathrm{~b}$ and d), as discussed in Itahashi et al. (2015). It was interesting to find that the trends in the $\mathrm{NO}_{x} / \mathrm{SO}_{2}$ emission ratio and the $\mathrm{NO}_{2} / \mathrm{SO}_{2}$ column ratio were again flat during Phase III. This can be explained by the declines in both $\mathrm{NO}_{x}$ and $\mathrm{SO}_{2}$ emissions. Based on the spatial mapping of the $\mathrm{NO}_{2} / \mathrm{SO}_{2}$ column ratio (right part of Fig. 3), the $\mathrm{NO}_{2} / \mathrm{SO}_{2}$ column ratio was substantially lower than 1.0 (red in the right panels of Fig. 3) above China during the first half of Phase II and subsequently increased above 1.0 (yellow to green in the right panels of Fig. 3) during the latter half of Phase II and into Phase III. An increase was found over all of China during Phase II, but 
Table 3. Statistical analysis of average values and linear trends for $\mathrm{NO}_{3}^{-} /$nss- $\mathrm{SO}_{4}^{2-}$ concentration in precipitation (Ratio) in precipitation over China, Korea, and Japan during phases I, II, and III.

\begin{tabular}{lcr|cr|cr}
\hline & \multicolumn{2}{c}{ Phase I (2001-2005) } & Phase II (2006-2010) & \multicolumn{2}{c}{ Phase III (2011-2015) } \\
\cline { 2 - 7 } & Mean & Trend & Mean & Trend & Mean & Trend \\
\hline Ratio $\left(\mu \mathrm{eq} \mu \mathrm{eq}^{-1}\right)$ & $-3.3 \pm 2.7$ & $0.37(N=31)$ & $+14.8 \pm 1.9^{\mathrm{c}}$ & $0.46(N=28)$ & $+10.1 \pm 3.8^{\mathrm{a}}$ \\
\hline China & $0.29(N=35)$ & & & \\
Korea & $0.62(N=11)$ & $-4.9 \pm 1.9^{\mathrm{a}}$ & $0.66(N=15)$ & $+13.6 \pm 4.7^{\mathrm{a}}$ & $0.86(N=15)$ & $+3.9 \pm 2.6$ \\
Japan & $0.58(N=44)$ & $-0.3 \pm 1.9$ & $0.60(N=56)$ & $+3.6 \pm 1.3^{\mathrm{a}}$ & $0.67(N=56)$ & $+2.5 \pm 1.3$ \\
\hline
\end{tabular}

Note: total number of observation sites are shown in parentheses. Linear trends were estimated using linear regression and results are shown as rates $\left(\% \mathrm{yr}^{-1}\right)$. Significance levels are indicated by ${ }^{\mathrm{a}} p<0.05,{ }^{\mathrm{b}} p<0.01$, and ${ }^{\mathrm{c}} p<0.001$, and lack of mark indicates a lack of significance. Analysis for Korea during Phase I was for the 2002-2005 period.

only a slight increase over central China and decreases over north and south China were observed during Phase III (right panels of Fig. 4a and b). Such changes in the $\mathrm{NO}_{x} / \mathrm{SO}_{2}$ emission ratio were highly correlated with the variation in Ratio over China. Ratio was almost 0.3 during Phase I and subsequently increased to 0.5 during Phase II, with a trend of $+14.8 \pm 1.9 \% \mathrm{yr}^{-1}(p<0.001)$, and to approximately $0.4-$ 0.6 during Phase III, with a trend of $+10.1 \pm 3.8 \% \mathrm{yr}^{-1}$ $(p<0.05)$. The analyses of different site types for EANET observations over China (Fig. 5b; see Table 1 for classification) revealed that the mean values for urban sites and rural and remote sites were highly correlated, with a correlation coefficient of 0.65 . In addition to the variation in Ratio based on EANET observations for urban sites and rural and remote sites, other observations through IMPACTS, BNU, and LAPC/IAP/CAS also indicated similar variation in $R a$ tio. Based on the IMPACTS dataset, which covered southern China with extensive data in 2001-2003, Ratio in China during Phase I was approximately 0.2 , which was much lower than the current (Phase III) status. Although $\mathrm{NO}_{3}^{-}$and nss$\mathrm{SO}_{4}^{2-}$ concentrations in precipitation were higher than those in the EANET observation dataset, observations at BNU revealed a Ratio of 0.31, which was consistent with EANET observation results. A coordinated observation network by LAPC/IAP/CAS, which operated for 3 years around Beijing, indicated an increasing trend during Phase II from 0.39 in 2008 to 0.59 in 2010 . These results obtained from multiple observations reinforce the idea that Ratio observed in the EANET network is representative of the precipitation chemistry in China.

In our previous studies (Itahashi et al., 2014a, 2015), we highlighted the impact of the $\mathrm{NO}_{x} / \mathrm{SO}_{2}$ emission ratio in China on the Ratio over downwind countries, including Korea and Japan. $\mathrm{NO}_{x} / \mathrm{SO}_{2}$ emissions and the $\mathrm{NO}_{2} / \mathrm{SO}_{2}$ column ratio in Korea showed complex variation. These parameters increased during Phase I, stayed essentially flat during Phase II, and increased slightly or remained flat during Phase III. It should be noted that the $\mathrm{NO}_{x} / \mathrm{SO}_{2}$ emission ratio and $\mathrm{NO}_{2} / \mathrm{SO}_{2}$ column ratio were not correlated in some parts of Korea. In particular, a flat trend was ob- served for the $\mathrm{NO}_{x} / \mathrm{SO}_{2}$ emission ratio from 2006 to 2007, with a decline in the $\mathrm{NO}_{2} / \mathrm{SO}_{2}$ column ratio; later, there was a flat trend for the $\mathrm{NO}_{x} / \mathrm{SO}_{2}$ emission ratio from 2010 to 2011 , with an increase in the $\mathrm{NO}_{2} / \mathrm{SO}_{2}$ column ratio. These discrepancies are attributed to complications from using the $\mathrm{SO}_{2}$ column as a proxy for $\mathrm{SO}_{2}$ emissions over Korea. Ratio over Korea was almost 0.6 during Phase I, with a trend of $-4.9 \pm 1.9 \% \mathrm{yr}^{-1}(p<0.05)$. This subsequently increased to 0.8 during Phase II, with a trend of $+13.6 \pm 4.7 \% \mathrm{yr}^{-1}$ $(p<0.05)$, and to around $0.8-1.0$ during Phase III, with a trend of $+3.9 \pm 2.6 \% \mathrm{yr}^{-1}$ (not significant). Considering the $\mathrm{NO}_{x} / \mathrm{SO}_{2}$ emission ratio during Phase II, the variation in Ratio in Korea may be connected to the variation in Ratio in China.

In Japan, both the $\mathrm{NO}_{x} / \mathrm{SO}_{2}$ emission ratio and $\mathrm{NO}_{2} / \mathrm{SO}_{2}$ column ratio exhibited declining trends during the 15 -year period. However, the long-term variation in Ratio did not show a decreasing trend. The Ratio over Japan was almost 0.6 during Phase I, with a trend of $-0.3 \pm 1.9 \% \mathrm{yr}^{-1}$ (not significant), subsequently increased to 0.7 during Phase II, with a trend of $+3.6 \pm 1.3 \% \mathrm{yr}^{-1}$ $(p<0.05)$, and remained level at approximately 0.7 during Phase III, with a trend of $+2.5 \pm 1.3 \% \mathrm{yr}^{-1}$ (not significant). Considering the continuous decline in the $\mathrm{NO}_{x} / \mathrm{SO}_{2}$ emission ratio during the 15-year period, the variation in Ratio in Japan appears to be related to the variation in Ratio in China.

The relationships between Ratio over China and Ratio over Korea or Japan are displayed in a scatterplot (Fig. 6). These data clearly illustrate that the Ratio over China and Korea and the Ratio over China and Japan dramatically changed over time. Along with the variation in the $\mathrm{NO}_{x} / \mathrm{SO}_{2}$ emission ratio and $\mathrm{NO}_{2} / \mathrm{SO}_{2}$ column ratio in China, Ratio in precipitation over China was flat, then increased, and then returned to a flat trend during the 15 -year period. The variation over China was related to patterns of variation over Korea and Japan, with correlation coefficients of 0.84 and 0.81 , respectively $(p<0.001)$. These results revealed the impact of emission changes in China and the variation in precipitation chemistry on a regional scale in East Asia. 

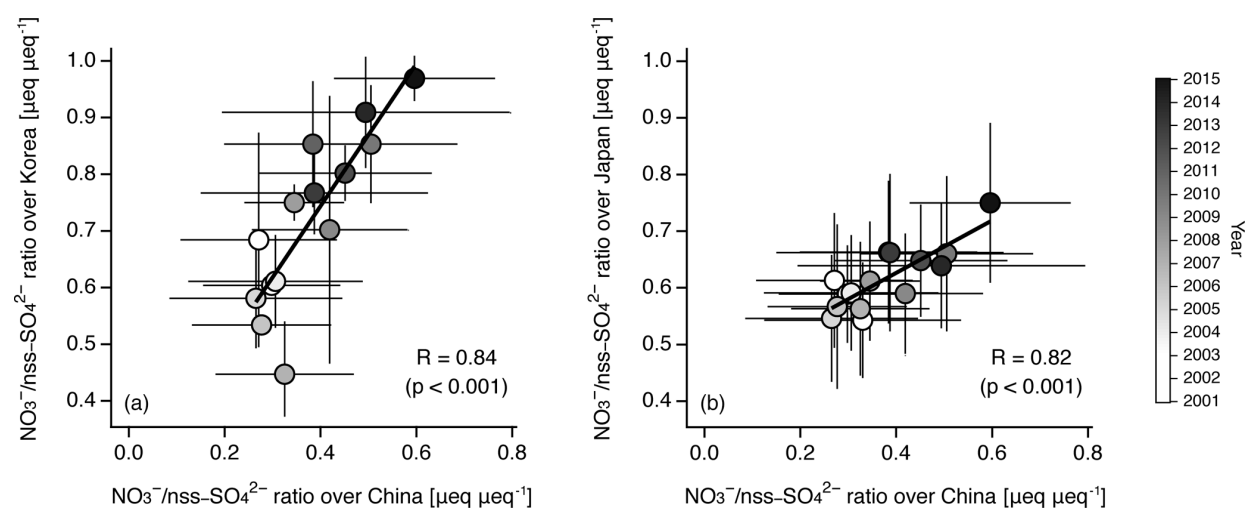

Figure 6. Scatterplots of (a) the $\mathrm{NO}_{3}^{-} / \mathrm{nss}^{-\mathrm{SO}_{4}^{2-}}$ concentration in precipitation (Ratio) in China and Korea and (b) those in China and Japan. Each circle indicates the annual mean Ratio, and the color indicates the year.

(i) China

(a) $\mathrm{NO}_{3}^{-}$wet deposition amount

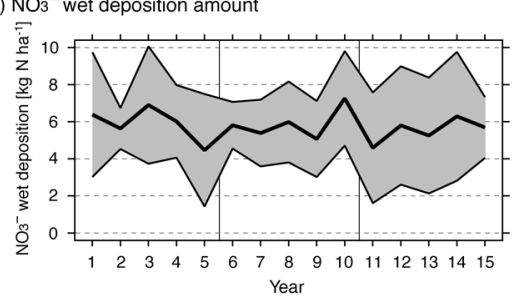

(b) nss-SO ${ }^{2-}$ wet deposition amount

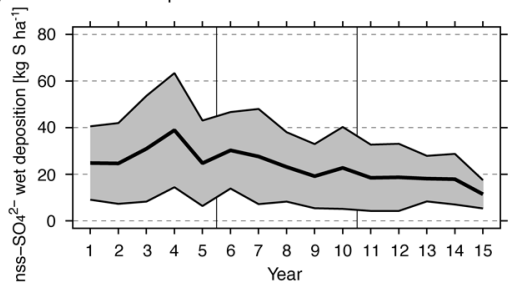

(ii) Korea
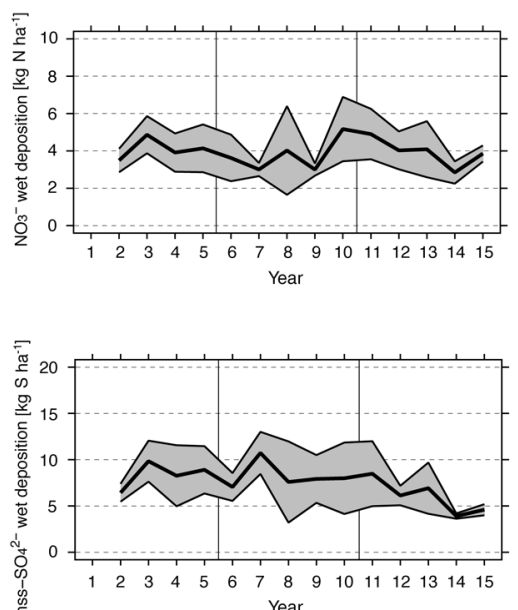

(iii) Japan
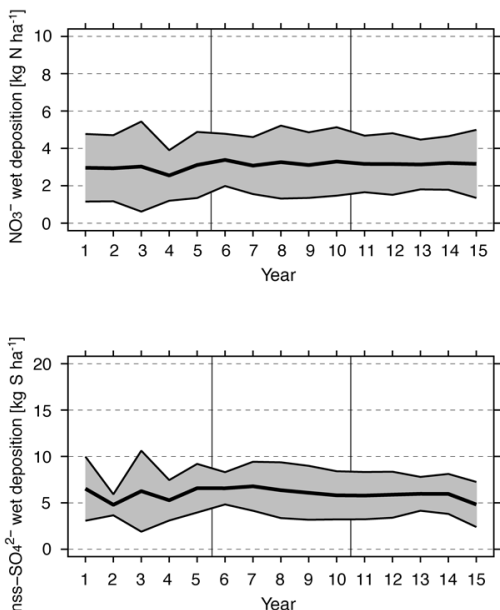

(c) Sum of $\mathrm{NO}_{3}{ }^{-}$and nss- $\mathrm{SO}_{4}{ }^{2-}$ wet deposition amount with $\mathrm{NO}_{3}{ }^{-}$wet deposition fraction
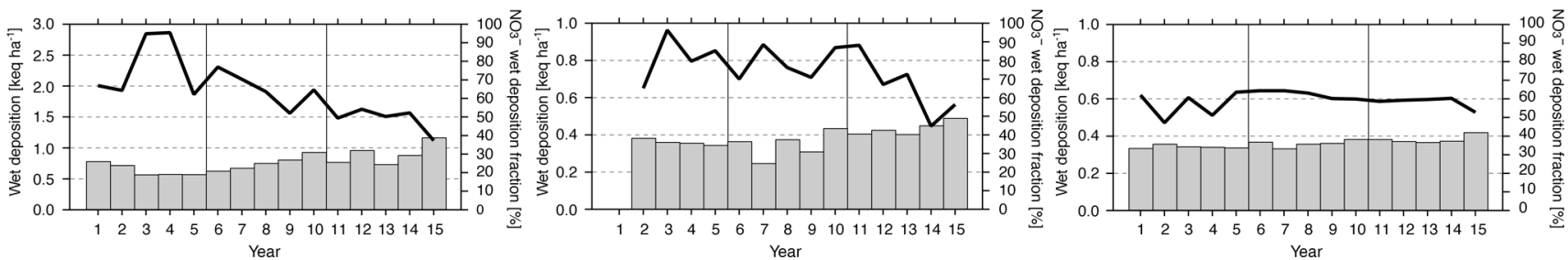

Figure 7. Long-term temporal variation in the (a) $\mathrm{NO}_{3}^{-}$wet deposition $\left(\mathrm{kg} \mathrm{Nha}^{-1}\right)$, (b) $\mathrm{nss}_{-} \mathrm{SO}_{4}^{2-}$ wet deposition $\left(\mathrm{kg} \mathrm{Sha}^{-1}\right)$, and (c) sum of $\mathrm{NO}_{3}^{-}$and nss- $\mathrm{SO}_{4}^{2-}$ wet deposition (keq ha ${ }^{-1}$ ) with the $\mathrm{NO}_{3}^{-}$fraction during 2001-2015 over (i) China, (ii) Korea, and (iii) Japan. One standard deviation across observation sites is indicated by the shaded area in $(\mathbf{a}, \mathbf{b})$. The numbers at the bottom indicate the number of years after 2000 (e.g., 5 indicates 2005 and 10 indicates 2010).

\subsection{Long-term trend in wet deposition}

Finally, we focused on wet deposition, which was calculated by multiplying the chemical concentration in precipitation with the precipitation amount. Monthly data were checked via an outlier test for the chemical concentration, and the annual accumulated wet deposition was computed for years in which there was at least 9 months of coverage. The long-term temporal variation in $\mathrm{NO}_{3}^{-}$and nss- $\mathrm{SO}_{4}^{2-}$ wet deposition over China, Korea, and Japan are shown in Fig. 7. Statistical analyses of averages values and trends during phases I, II, and III are summarized in Table 4. $\mathrm{NO}_{3}^{-}$wet deposition amounts were approximately 6,4 , and $3 \mathrm{~kg} \mathrm{~N} \mathrm{ha}^{-1}$ over China, Korea, and Japan, respectively, and the year-to-year variation was high. In a statistical analysis of the $\mathrm{NO}_{3}^{-}$wet deposition amount, there were no significant trends for China, Ko- 
Table 4. Statistical analysis of average values and linear trends for $\mathrm{NO}_{3}^{-}$and nss- $\mathrm{SO}_{4}^{2-}$ wet deposition over China, Korea, and Japan during phases I, II, and III.

\begin{tabular}{|c|c|c|c|c|c|c|}
\hline & \multicolumn{2}{|c|}{ Phase I (2001-2005) } & \multicolumn{2}{|c|}{ Phase II (2006-2010) } & \multicolumn{2}{|c|}{ Phase III (2011-2015) } \\
\hline & Mean & Trend & Mean & Trend & Mean & Trend \\
\hline \multicolumn{7}{|c|}{$\mathrm{NO}_{3}^{-}$wet deposition $\left(\mathrm{kg} \mathrm{Nha}^{-1}\right)$} \\
\hline China & 5.88 & $-5.9 \pm 4.6$ & 5.90 & $+4.4 \pm 4.5$ & 5.53 & $+4.9 \pm 3.2$ \\
\hline Korea & 4.10 & $+2.4 \pm 7.5$ & 3.76 & $+8.2 \pm 7.3$ & 3.95 & $-8.3 \pm 4.8$ \\
\hline Japan & 2.92 & $-0.3 \pm 2.7$ & 3.23 & $-0.4 \pm 1.5$ & 3.17 & $+0.2 \pm 0.3$ \\
\hline \multicolumn{7}{|c|}{ nss-SO $\mathrm{SO}_{4}^{2-}$ wet deposition $\left(\mathrm{kg} \mathrm{Sha}^{-1}\right)$} \\
\hline China & 28.80 & $+4.9 \pm 7.4$ & 24.57 & $-9.6 \pm 3.4^{\mathrm{a}}$ & 16.90 & $-8.8 \pm 4.3$ \\
\hline Korea & 8.36 & $+7.0 \pm 8.0$ & 8.26 & $-1.1 \pm 6.3$ & 6.01 & $-16.7 \pm 5.6^{\mathrm{a}}$ \\
\hline Japan & 5.88 & $+1.0 \pm 5.0$ & 6.32 & $-3.5 \pm 0.9^{a}$ & 5.68 & $-3.2 \pm 2.5$ \\
\hline
\end{tabular}

Note: linear trends were estimated using linear regression and results are shown as rates $\left(\% \mathrm{yr}^{-1}\right)$.

Significance levels are indicated by ${ }^{\mathrm{a}} p<0.05,{ }^{\mathrm{b}} p<0.01$, and ${ }^{\mathrm{c}} p<0.001$, and lack of a mark indicates a lack of significance. Analysis for Korea during Phase I was for the 2002-2005 period.

rea, and Japan during each phase (Fig. 7a). With respect to reactive nitrogen $(\mathrm{Nr})$ deposition, the threshold value of $10 \mathrm{~kg} \mathrm{Nha}^{-1}$ has been established (e.g., Bleeker et al., 2011). In the 15-year long-term analysis, the wet deposition of $\mathrm{NO}_{3}^{-}$ accounted for more than half of this threshold $\mathrm{Nr}$ deposition in China and about one-third in Korea and Japan.

The nss- $\mathrm{SO}_{4}^{2-}$ wet deposition exhibited decreasing trends during Phase II and III. The amount over China was around $30 \mathrm{~kg} \mathrm{Sha}^{-1}$ during Phase I and below $20 \mathrm{~kg} \mathrm{Sha}^{-1}$ during III, and the amounts over Korea and Japan decreased to about 2 and $1 \mathrm{~kg} \mathrm{Sha}^{-1}$, respectively. Based on a statistical analysis, nss- $\mathrm{SO}_{4}^{2-}$ wet deposition showed increasing (nonsignificant) trends during Phase I and decreasing trends during phases II and III. Decreasing trends over China and Japan during Phase II and over Korea during Phase III were significant $(p<0.05)$ (Fig. 7b). It should be emphasized that precipitation over China, Korea, and Japan during Phase II and over China during Phase III increased. Our results indicate that the decreasing trends in the nss- $\mathrm{SO}_{4}^{2-}$ wet deposition were caused by a strong decline in the nss- $\mathrm{SO}_{4}^{2-}$ concentration in precipitation, which counteracted the increase in overall precipitation. The reduction in $\mathrm{SO}_{2}$ emissions over Korea and Japan might partially contribute to the decline in the nss- $\mathrm{SO}_{4}^{2-}$ concentration in precipitation. However, taking into account the correlation between precipitation chemistry over East Asia and emission changes in China, the $\mathrm{SO}_{2}$ emission reduction in China after 2005-2006 strongly impacted both local deposition and downwind deposition.

To consider the impact of wet deposition from $\mathrm{NO}_{3}^{-}$and nss- $\mathrm{SO}_{4}^{2-}$, the sum was calculated and is shown in Fig. 7c as an equivalent (eq) basis; additionally, the fraction of this sum attributed to $\mathrm{NO}_{3}^{-}$wet deposition was also analyzed (expressed as a percentage). For the 15-year analysis period, it has been suggested that nss- $\mathrm{SO}_{4}^{2-}$ wet deposition is reduced in East Asia. The results indicated that the fraction of $\mathrm{NO}_{3}^{-}$ wet deposition increased gradually during the 15 -year period over East Asia, indicating that further attention should be paid to the deposition of $\mathrm{NO}_{3}^{-}$and related $\mathrm{Nr}$ species. These results are consistent with those of previous analyses of several cities in China, including Nanjing (Tu et al., 2005), Shenzhen (Huang et al., 2008), Guangzhou (Fang et al., 2013), the Pearl River Delta region (Lu et al., 2015), Tieshanping, which is one of the IMPACTS sites (Yu et al., 2017), and Beijing (Wang et al., 2012). Our study reinforced these inferences on a larger scale over East Asia. Excess $\mathrm{Nr}$ deposition will result in eutrophication, which normally reduces biodiversity. Transboundary nitrogen air pollution and deposition have been found over East Asia (Itahashi et al., 2016, 2017b). To reduce their impact, further understanding of $\mathrm{NH}_{3}$ emissions will be important to develop a multipollutant control strategy (Zhao et al., 2009). In China, the $\mathrm{pH}$ of precipitation has not been lower than those of Korea and Japan due to substantial buffering species (Duan et al., 2016); therefore, base cations should be included in forthcoming analyses.

\section{Summary and future perspectives}

In this study, the chemistry of precipitation in East Asia in 2001-2015 was evaluated, with a focus on the behavior of Ratio (defined as the $\mathrm{NO}_{3}^{-} / \mathrm{nss}-\mathrm{SO}_{4}^{2-}$ concentration in precipitation). The monitoring networks over East Asia were initially used, and the study was augmented by intense observation campaigns over southern and northern China. $\mathrm{NO}_{2}$ and $\mathrm{SO}_{2}$ column density satellite observations were used as proxies for $\mathrm{NO}_{x}$ and $\mathrm{SO}_{2}$ emissions, and this was a key update from our previous studies (Itahashi et al., 2014a, 2015). The results for the $\mathrm{NO}_{3}^{-}$concentration in precipitation suggested 
that there is no clear relation between $\mathrm{NO}_{x}$ emissions and corresponding trends in China, Korea, and Japan. In comparison, the nss- $\mathrm{SO}_{4}^{2-}$ concentration in precipitation was partially correlated to the $\mathrm{SO}_{2}$ emissions in China, and a corresponding (but nonsignificant) decline in Korea and Japan was also found. The analysis of Ratio clarified the trend (i.e., flat, followed by an increase and subsequent flattening) during the 15-year period in China, Korea, and Japan, and this variation was correlated to the $\mathrm{NO}_{x} / \mathrm{SO}_{2}$ emission ratio and the $\mathrm{NO}_{2} / \mathrm{SO}_{2}$ column ratio in China. The initial flat trend was due to the increases in both $\mathrm{NO}_{x}$ and $\mathrm{SO}_{2}$ emission in China, the subsequent increase was caused by the increase in $\mathrm{NO}_{x}$ emissions and the decrease in $\mathrm{SO}_{2}$ emission in China, and the eventual flat trend was due to decreases in both $\mathrm{NO}_{x}$ and $\mathrm{SO}_{2}$ emission in China. Due to the impact of upwind regions, it is difficult to use the $\mathrm{SO}_{2}$ column as an accurate proxy of $\mathrm{SO}_{2}$ emissions in Korea. Despite the increasing trends in the precipitation amount, decreasing trends for nss$\mathrm{SO}_{4}^{2-}$ wet deposition over China were observed after 20052006 and matched reductions in $\mathrm{SO}_{2}$ emissions from China. This decrease in China triggered the decreases in nss- $\mathrm{SO}_{4}^{2-}$ wet deposition over Korea and Japan. Both nitrogen and sulfur compounds pose acidification risks in ecosystems via atmospheric deposition processes. During the 15-year period analyzed in this study, sulfur wet deposition in East Asia decreased. This reduction seems to be important for future patterns, and additional studies focused on nitrogen are needed. Although this study was focused on wet deposition, a synergetic analysis of dry deposition processes is also needed to understand the impact of total wet and dry deposition on East Asian ecosystems.

Data availability. All of the data used in this study is publicly available. The data set of the ground-based and satellite observations and emission inventories are available from each reference as described in Sect. 2. For further information, please contact Syuichi Itahashi at the Central Research Institute of Electric Power Industry via email (isyuichi@criepi.denken.or.jp).

Author contributions. SI performed the analysis of observation, emission inventory, and satellite data and prepared the manuscript with contributions from all coauthors. KY and IU conducted the satellite data analysis and discussed the results. HH and SF measured precipitation at the Komae site and performed the analysis. YP and YW measured precipitation at 10 observation sites around Beijing and performed the analysis.

Competing interests. The authors declare that they have no conflict of interest.

Special issue statement. This article is part of the special issue "Global and regional assessment of intercontinental transport of air pollution: results from HTAP, AQMEII and MICS". It is not associated with a conference.

Acknowledgements. The authors thank EANET and JMA for providing wet-deposition measurement data and the IMPACTS campaign and BNU for opening their measurement data up to the public. The authors also acknowledge NASA for providing OMI satellite data for $\mathrm{NO}_{2}$ and $\mathrm{SO}_{2}$. Syuichi Itahashi acknowledges the support of JSPS KAKENHI (Grant JP16K21690). Yuepeng Pan acknowledges the National Key Research and Development Program of China (Grants 2017YFC0210101, 2016YFD0800302) and the National Natural Science Foundation of China (Grant 41405144) for financial support. The authors are grateful to two reviewers for their constructive comments.

Edited by: Frank Dentener

Reviewed by: two anonymous referees

\section{References}

Ban, S., Matsuda, K., Sato, K., and Ohizumi, T.: Longterm assessment of nitrogen deposition at remote EANET sites in Japan, Atmos. Environ., 146, 70-78, https://doi.org/10.1016/j.atmosenv.2016.04.015, 2016.

Bleeker, A., Hicks, W. K., Dentener, F., Galloway, J., and Erisman, J. W.: N deposition as a threat to the world's protected areas under the convention on biological diversity, Environ. Pollut., 159, 2280-2288, https://doi.org/10.1016/j.envpol.2010.10.036, 2011.

Brenot, H., Theys, N., Clarisse, L., van Geffen, J., van Gent, J., Van Roozendael, M., van der A, R., Hurtmans, D., Coheur, P.-F., Clerbaux, C., Valks, P., Hedelt, P., Prata, F., Rasson, O., Sievers, K., and Zehner, C.: Support to Aviation Control Service (SACS): an online service for near-real-time satellite monitoring of volcanic plumes, Nat. Hazards Earth Syst. Sci., 14, 1099-1123, https://doi.org/10.5194/nhess-14-1099-2014, 2014.

Cui, J., Zhou, J., Peng, Y., He, Y., Yang, H., and Mao, J.: Atmospheric wet deposition of nitrogen and sulfur to a typical red soil agroecosystem in Southeast China during the ten-yearss monsoon seasons (2003-2012), Atmos. Environ., 82, 121-129, https://doi.org/10.1016/j.atmosenv.2013.10.023, 2014.

Duan, L., Yu, Q., Zhang, Q., Wang, Z., Pan, Y., Larssen, T., Tang, J., and Mulder, J.: Acid deposition in Asia: Emissions, depositions, and ecosystem effects, Atmos. Environ., 146, 55-69, https://doi.org/10.1016/j.atmosenv.2016.07.018, 2016.

EANET: Quality Assurance/Quality Control (QA/QC) Program for Wet Deposition Monitoring in East Asia, available at: http:// www.eanet.asia/product/qaqc/qaqcwet.pdf (last access: 19 April 2017), 2000.

EANET: Technical Manual for Wet Deposition Monitoring in East Asia, available at: http://www.eanet.asia/product/manual/ techwet.pdf (last access: 19 April 2017), 2010.

EANET (Acid Deposition Monitoring Network in East Asia): available at: http://www.eanet.asia/index.html, last access: 19 April 2017.

Endo, T., Yagoh, H., Sato, K., Matsuda, K., Hayashi, K., Noguchi, I., and Sawada, K.: Regional characteristics of dry deposition of sulfur and nitrogen compounds at EANET sites in 
Japan from 2003 to 2012, Atmos. Environ., 45, 1259-1267, https://doi.org/10.1016/j.atmosenv.2010.12.003, 2011.

Fang, Y., Wang, X., Zhu, F., Wu, Z., Li, J., Zhong, L., Chen, D., and Yoh, M.: Three-decade changes in chemical composition of precipitation in Guangzhou city, southern China: has precipitation recovered from acidification following sulphur dioxide emission control?, Tellus B, 6, 20213, https://doi.org/10.3402/tellusb.v65i0.20213, 2013.

Fujita, S., Takahashi, A., Weng, J.-H., Huang, L.-F., Kim, H.-K., Li, C.-K., Huang, F. T. C., and Jeng, F-T.: Precipitation chemistry in East Asia, Atmos. Environ., 34, 525-537, 2000.

Fujita, S., Takahashi, A., and Sakurai, T.: The wet deposition of acid and some major ions over the Japanese Archipelago, Tellus B, 55, 23-34, 2003.

Han, K. M., Lee, S., Chang, L. S., and Song, C. H.: A comparison study between CMAQ-simulated and OMI-retrieved $\mathrm{NO}_{2}$ columns over East Asia for evaluation of $\mathrm{NO}_{x}$ emission fluxes of INTEX-B, CAPSS, and REAS inventories, Atmos. Chem. Phys., 15, 1913-1938, https://doi.org/10.5194/acp15-1913-2015, 2015.

Huang, Y. L., Wang, Y. L., and Zhang, L. P.: Long-term trend of chemical composition of wet atmospheric precipitation during 1986-2006 at Shenzhen City, China, Atmos. Environ., 42, 37403750, https://doi.org/10.1016/j.atmosenv.2007.12.063, 2008.

Itahashi, S., Uno, I., Yumimoto, K., Irie, H., Osada, K., Ogata, K., Fukushima, H., Wang, Z., and Ohara, T.: Interannual variation in the fine-mode MODIS aerosol optical depth and its relationship to the changes in sulfur dioxide emissions in China between 2000 and 2010, Atmos. Chem. Phys., 12, 2631-2640, https://doi.org/10.5194/acp-12-2631-2012, 2012.

Itahashi, S., Uno, I., Hayami, H., and Fujita, S.: Modeling investigation of controlling factors in the increasing ratio of nitrate to non-seasalt sulfate in precipitation over Japan, Atmos. Environ., 92, 171-177, https://doi.org/10.1016/j.atmosenv.2014.04.022, 2014a.

Itahashi, S., Uno, I., Irie, H., Kurokawa, J.-I., and Ohara, T.: Regional modeling of tropospheric $\mathrm{NO}_{2}$ vertical column density over East Asia during the period 2000-2010: comparison with multisatellite observations, Atmos. Chem. Phys., 14, 3623-3635, https://doi.org/10.5194/acp-14-3623-2014, 2014b.

Itahashi, S., Uno, I., Hayami, H., and Fujita, S.: variation of the ratio of nitrate to non-seasalt sulfate in precipitation over East Asia with emissions from China, Atmos. Environ., 118, 87-97, https://doi.org/10.1016/j.atmosenv.2015.07.032, 2015.

Itahashi, S., Hayami, H., Uno, I., Pan, X., and Uematsu, M.: Importance of coarse-mode nitrate produced via sea-salt as atmospheric input to East Asian oceans, Geophys. Res, Lett., 43, 5483-5491, https://doi.org/10.1002/2016GL068722, 2016.

Itahashi, S., Hayami, H., Yumimoto, K., and Uno, I.: Chinese province-scale source apportionments for sulfate aerosol in 2005 evaluated by the tagged tracer method, Environ. Pollut., 220, 1366-1375, https://doi.org/10.1016/j.envpol.2016.10.098, $2017 \mathrm{a}$.

Itahashi, S., Uno, I., Osada, K., Kamiguchi, Y., Yamamoto, S., Tamura, K., Wang, Z., Kurosaki, Y., and Kanaya, Y.: Nitrate transboundary heavy pollution over East Asia in winter, Atmos. Chem. Phys., 17, 3823-3843, https://doi.org/10.5194/acp17-3823-2017, $2017 \mathrm{~b}$.
Irie, H., Muto, T., Itahashi, S., Kurokawa, J., and Uno, I.: Turnaround of tropospheric nitrogen dioxide pollution trends in China, Japan, and South Korea, SOLA, 12, 170-174, https://doi.org/10.2151/sola.2016-035, 2016.

JATOP (Japan Auto-Oil Program): Emission estimates from motor vehicles, JPEC-2011AQ-02-06, Tokyo, Japan, 2012a (in Japanese).

JATOP (Japan Auto-Oil Program): Emission estimates from sources other than motor vehicles, JPEC-2011AQ-02-07, Tokyo, Japan, $2012 b$ (in Japanese).

Kajino, M., Ueda, H., Sato, K., and Sakurai, T.: Spatial distribution of the source-receptor relationship of sulfur in Northeast Asia, Atmos. Chem. Phys., 11, 6475-6491, https://doi.org/10.5194/acp-11-6475-2011, 2011.

Kajino, M., Sato, K., Inomata, Y., and Ueda, H.: Source-receptor relationships of nitrate in Northeast Asia and influence of sea salt on the long-range transport of nitrate, Atmos. Environ., 59, 461-475, https://doi.org/10.1016/j.atmosenv.2013.06.024, 2013.

Koukouli, M. E., Balis, D. S., van der A, R. J., Theys, N., Hedelt, P., Richter, A., Krotkov, N., Li, C., and Taylor, M.: Anthropogenic sulphur dioxide load over China as observed from different satellite sensors, Atmos. Environ., 145, 45-59, https://doi.org/10.1016/j.atmosenv.2016.09.007, 2016.

Krotkov, N. A.: OMI/Aura $\mathrm{NO}_{2}$ Cloud-Screened Total and Tropospheric Column L3 Global Gridded 0.25 degree $\times 0.25$ degree V3, NASA Goddard Space Flight Center, Goddard Earth Sciences Data and Information Services Center (GES DISC), https://doi.org/10.5067/Aura/OMI/DATA3007, 2013.

Krotkov, N. A., Li, C., and Leonard, P.: OMI/Aura Sulfur Dioxide $\left(\mathrm{SO}_{2}\right)$ Total Column L3 1 day Best Pixel in 0.25 degree $\times 0.25$ degree V3, Greenbelt, MD, USA, Goddard Earth Sciences Data and Information Services Center (GES DISC), https://doi.org/10.5067/Aura/OMI/DATA3008, 2015.

Krotkov, N. A., McLinden, C. A., Li, C., Lamsal, L. N., Celarier, E. A., Marchenko, S. V., Swartz, W. H., Bucsela, E. J., Joiner, J., Duncan, B. N., Boersma, K. F., Veefkind, J. P., Levelt, P. F., Fioletov, V. E., Dickerson, R. R., He, H., Lu, Z., and Streets, D. G.: Aura OMI observations of regional $\mathrm{SO}_{2}$ and $\mathrm{NO}_{2}$ pollution changes from 2005 to 2015, Atmos. Chem. Phys., 16, 46054629, https://doi.org/10.5194/acp-16-4605-2016, 2016.

Krotkov, N. A., Lamsal, L. N., Celarier, E. A., Swartz, W. H., Marchenko, S. V., Bucsela, E. J., Chan, K. L., Wenig, M., and Zara, M.: The version $3 \mathrm{OMI} \mathrm{NO}_{2}$ standard product, Atmos. Meas. Tech., 10, 3133-3149, https://doi.org/10.5194/amt10-3133-2017, 2017.

Kuribayashi, M., Ohara, T., Morino, Y., Uno, I., Kurokawa, J., and Hara, H.: Long-term trends of sulfur deposition in East Asia, Atmos. Environ., 59, 461-475, https://doi.org/10.1016/j.atmosenv.2012.04.060, 2012.

Kurokawa, J., Ohara, T., Morikawa, T., Hanayama, S., JanssensMaenhout, G., Fukui, T., Kawashima, K., and Akimoto, H.: Emissions of air pollutants and greenhouse gases over Asian regions during 2000-2008: Regional Emission inventory in ASia (REAS) version 2, Atmos. Chem. Phys., 13, 11019-11058, https://doi.org/10.5194/acp-13-11019-2013, 2013.

Larssen, T., Tang, D. G., and He, Y. (Eds.): Integrated Monitoring Program on Acidification of Chinese Terrestrial Systems - IMPACTS, Annual Report - Results 2003, 2004; NIVA Report SNO 4905/2004; Norwegian Institute for Water Research, Oslo, 2004. 
Larssen, T., Lydersen, E., Tang, D., He, Y., Gao, J., Liu, H., Duan, L., Seip, H. M., Vogt, R. D., Mulder, J., Shao, M., Wang Y., Shang, H., Zhang, X., Solberg, S. Aas, W., Okland, T., Eilertsen, O., Angell, V., Li, Q., Zhao, D., Xiang, R., Xiao, J., and Luo, J.: Acid Rain in China, Environ. Sci. Technol., 40, 418-425, 2006.

Lee, C., Martin, R. V., Donkelaar, A., Lee, H., Dickerson, R. R., Hains, J. C., Krotkov, N., Richter, A., Vinnikov, K., and Schwab, J. J.: $\mathrm{SO}_{2}$ emissions and lifetimes: Estimates from inverse modeling using in situ and global space-based (SCIAMACHY and OMI) observations, J. Geophys. Res.-Atmos., 116, D06304, https://doi.org/10.1029/2010JD014758, 2011.

Li, C., Zhang, Q., Krotkov, N. A., Streets, D. G., He, K., Tsay, S.-C., and Gleason, J. F.: Recent Large Reduction in Sulfur Dioxide Emissions from Chinese Power Plants Observed by the Ozone Monitoring Instrument, Geophys. Res. Lett., 37, 1-6, https://doi.org/10.1029/2010GL042594, 2010.

Li, C., Joiner, J., Krotkov, N. A., and Bhartia, P. K.: A fast and sensitive new satellite $\mathrm{SO}_{2}$ retrieval algorithm based on principal component analysis: Application to the ozone monitoring instrument, Geophys. Res. Lett., 40, 6314-6318, https://doi.org/10.1002/2013GL058134, 2013.

Li, M., Zhang, Q., Kurokawa, J.-I., Woo, J.-H., He, K., Lu, Z., Ohara, T., Song, Y., Streets, D. G., Carmichael, G. R., Cheng, Y., Hong, C., Huo, H., Jiang, X., Kang, S., Liu, F., Su, H., and Zheng, B.: MIX: a mosaic Asian anthropogenic emission inventory under the international collaboration framework of the MICS-Asia and HTAP, Atmos. Chem. Phys., 17, 935-963, https://doi.org/10.5194/acp-17-935-2017, 2017.

Lu, X., Fung, J. C. H., and Wu, D.: Modeling wet deposition of acid substances over the PRD region in China, Atmos. Environ., 122, 819-828, https://doi.org/10.1016/j.atmosenv.2015.09.035, 2015.

Mijling, B., van der A, R. J., and Zhang, Q.: Regional nitrogen oxides emission trends in East Asia observed from space, Atmos. Chem. Phys., 13, 12003-12012, https://doi.org/10.5194/acp-1312003-2013, 2013.

Miyazaki, K., Eskes, H. J., and Sudo, K.: Global $\mathrm{NO}_{x}$ emission estimates derived from an assimilation of OMI tropospheric $\mathrm{NO}_{2}$ columns, Atmos. Chem. Phys., 12, 2263-2288, https://doi.org/10.5194/acp-12-2263-2012, 2012.

Morino, Y., Ohara, T., Kurokawa, J., Kuribayashi, M., Uno, I., and Hara, H.: Temporal variations of nitrogen wet depositions across Japan from 1989 to 2008, J. Geophys. Res.-Atmos., 116, D06307, https://doi.org/10.1029/2010JD015205, 2011.

NASA (National Aeronautics and Space Administration): Goddard Earth Sciences Data and Information Services Center (GES DISC), available at: https://disc.sci.gsfc.nasa.gov/Aura/ data-holdings/OMI, last access: 1 May 2017.

NIER (National Institute of Environmental Research): National Air Pollutants Emission Service, available at: http://airemiss.nier.go. kr/mbshome/mbs/airemiss/index.do, last access: 26 April 2017.

Pan, Y. P. and Wang, Y. S.: Atmospheric wet and dry deposition of trace elements at 10 sites in Northern China, Atmos. Chem. Phys., 15, 951-972, https://doi.org/10.5194/acp-15-9512015, 2015.

Pan, Y. P., Wang, Y. S., Tang, G. Q., and Wu, D.: Wet and dry deposition of atmospheric nitrogen at ten sites in Northern China, Atmos. Chem. Phys., 12, 6515-6535, https://doi.org/10.5194/acp12-6515-2012, 2012.
Pan, Y. P., Wang, Y. S., Tang, G. Q., and Wu, D.: Spatial distribution and temporal variations of atmospheric sulfur deposition in Northern China: insights into the potential acidification risks, Atmos. Chem. Phys., 13, 1675-1688, https://doi.org/10.5194/acp13-1675-2013, 2013.

Sickles II, J. E. and Shadwick, D. S.: Air quality and atmospheric deposition in the eastern US: 20 years of change, Atmos. Chem. Phys., 15, 173-197, https://doi.org/10.5194/acp-15-1732015, 2015.

Sun, Y., Zhuang, G., Wang, Y., Han, L., Guo, J., Dan, M., Zhang, W., Wang, Z., and Hao, Z.: The air-borne particulate pollution in Beijing - concentration, composition, distribution and sources, Atmos. Environ., 38, 5991-6004, https://doi.org/10.1016/j.atmosenv.2004.07.009, 2004

Takahashi, A. and Fujita, S.: Long-term trends in nitrate to nonseasalt sulfate ratio in precipitation collected in western Japan, Atmos. Environ., 34, 4551-4555, 2000.

Tang, A., Zhuang, G., Wang, Y., Yuan, H., and Sun, Y.: The chemistry of precipitation and its relation to aerosol in Beijing, Atmos. Environ., 39, 3397-3406, https://doi.org/10.1016/j.atmosenv.2005.02.001, 2005.

Tørseth, K., Aas, W., Breivik, K., Fjæraa, A. M., Fiebig, M., Hjellbrekke, A. G., Lund Myhre, C., Solberg, S., and Yttri, K. E.: Introduction to the European Monitoring and Evaluation Programme (EMEP) and observed atmospheric composition change during 1972-2009, Atmos. Chem. Phys., 12, 5447-5481, https://doi.org/10.5194/acp-12-5447-2012, 2012.

Tu, J., Wang, H. S., Zhang, Z. F., Jin, X., and Li, W. Q.: Trends in chemical composition of precipitation in Nanjing, China, during 1992-2003, Atmos. Res., 73, 283-298, https://doi.org/10.1016/j.atmosres.2004.11.002, 2005.

van $\operatorname{der}$ A, R. J., Mijling, B., Ding, J., Koukouli, M. E., Liu, F., Li, Q., Mao, H., and Theys, N.: Cleaning up the air: effectiveness of air quality policy for $\mathrm{SO}_{2}$ and $\mathrm{NO}_{x}$ emissions in China, Atmos. Chem. Phys., 17, 1775-1789, https://doi.org/10.5194/acp17-1775-2017, 2017.

Vet, R., Artz, R. S., Carou, S., Shaw, M., Ro, C.-U., Aas, W., Baker, A., Bowersox, V. C., Dentener, F., Galy-Lacaux, C., Hou, A., Piennar, J. J., Gillett, R., Forti, M. C., Gromov, S., Hara, H., Khodzher, T., Mahowald, N. M., Nickovic, S., Rao, P. S. P., and Reid, N. W.: A global assessment of precipitation chemistry and deposition of sulfur, nitrogen, sea salt, base cations, organic acids, acidity and pH, and phosphorous, Atmos. Environ., 93, 3100, https://doi.org/10.1016/j.atmosenv.2013.10.060, 2014.

Wang, S., Zhang, Q., Martin, R. V., Philip, S., Liu, F., Li, M., Jiang, X., and He, K.: Satellite measurements oversee China's sulfur dioxide emission reductions from coal-fired power plants, Environ. Res. Lett., 10, 114015, https://doi.org/10.1088/17489326/10/11/114015, 2015.

Wang, Y., Yu, W., Pan, Y., and Wu, D.: Acid neutralization of precipitation in Northern China, J. Air Waste Manage., 62, 204-211, https://doi.org/10.1080/10473289.2011.640761, 2012.

WMO GAW (World Meterological Organization Global Atmosphere Watch): Manual for the GAW precipitation chemistry programme, available at: https://library.wmo.int/pmb_ged/wmo-td_ 1251.pdf (last access: 19 February 2018), 2004.

Xia, Y., Zhao, Y., and Nielsen, C. P.: Benefits of China's efforts in gaseous pollutant control indicated by the bottom-up emissions 
and satellite observations 2000-2014, Atmos. Environ., 136, 4353, https://doi.org/10.1016/j.atmosenv.2016.04.013, 2016.

Yamashita, N., Sase, H., Ohizumi, T.,Kurokawa, J., Ohara, T., Morino, Y., Kuribayashi, M., Ohta, S., Kaneko, S., Hayashi, K., Fukuhara, H., and Hakamata, T.: Mapping the risk of surface water acidification based on cumulative acid deposition over the past 25 years in Japan, J. Forest Res., 21, 115-124, https://doi.org/10.1007/s10310-016-0523-8, 2016.

Yu, Q., Zhang, T., Ma, X., Kang, R., Mulder, J., Larssen, T., and Duan, L.: Monitoring effect of $\mathrm{SO}_{2}$ emission abatement on recovery of acidified soil and streamwater in southwest China, Environ. Sci. Technol., 51, 9498-9506, https://doi.org/10.1021/acs.est.7b01147, 2017.
Zhang, N., He, Y. Q., Cao, J. J., Ho, K. F., and Shen, Z. X.: Longterm trends in chemical composition of precipitation at Lijiang, southeast Tibetan Plateau, southwestern China, Atmos. Res., 106, 50-60, https://doi.org/10.1016/j.atmosres.2011.11.006, 2012.

Zhao, Y., Duan, L., Xing, J., Larssen, T., Nielsen, C. P., and Hao, J.: Soil acidification in China: Is controlling $\mathrm{SO}_{2}$ emissions enough?, Environ. Sci. Technol., 43, 8021-8026, https://doi.org/10.1021/es901430n, 2009. 